\title{
A new genus and two new species of Stevardiinae (Characiformes: Characidae) with a hypothesis on their relationships based on morphological and histological data
}

\author{
Katiane M. Ferreira ${ }^{1}$, Naércio A. Menezes ${ }^{1}$ and Irani Quagio-Grassioto ${ }^{2}$
}

Lepidocharax, new genus, and Lepidocharax diamantina and L. burnsi new species from eastern Brazil are described herein. Lepidocharax is considered a monophyletic genus of the Stevardiinae and can be distinguished from the other members of this subfamily except Planaltina, Pseudocorynopoma, and Xenurobrycon by having the dorsal-fin origin vertically aligned with the anal-fin origin, $v s$. dorsal fin origin anterior or posterior to anal-fin origin. Additionally the new genus can be distinguished from those three genera by not having the scales extending over the ventral caudal-fin lobe modified to form the dorsal border of the pheromone pouch organ or to represent a pouch scale in sexually mature males. In this paper, we describe these two recently discovered species and the ultrastructure of their spermatozoa.

O trabalho contém a descrição de um gênero novo, Lepidocharax, e duas espécies novas, Lepidocharax diamantina e L. burnsi do leste do Brasil. Lepidocharax é considerado um gênero monofilético de Stevardiinae e pode ser diferenciado dos outros membros desta subfamília, exceto Planaltina, Pseudocorynopoma e Xenurobrycon principalmente porque as duas espécies nele incluídas têm a origem da nadadeira dorsal verticalmente alinhada com a origem da nadadeira anal, vs. origem da nadadeira dorsal anterior ou posterior a origem da nadadeira anal. Adicionalmente, o novo gênero pode ser distinguido dos mesmos três gêneros por não possuir escamas modificadas localizadas no lobo ventral da nadadeira caudal, formando a borda dorsal do órgão produtor de feromônio ou uma escama modificada do mesmo órgão em machos sexualmente maduros. A ultraestrutura dos espermatozóides das duas espécies recentemente descobertas também é descrita.

Key words: Glandulocaudinae, Lepidocharax, Phylogeny, Spermatozoa.

\section{Introduction}

The presence of glandular tissue associated with modified scales on the caudal-fin of sexually mature males was used by Eigenmann (1914) to characterize the Glandulocaudinae, a group initially thought to be monophyletic, but recently split into two subfamilies: Glandulocaudinae and Stevardiinae (Menezes \& Weitzman, 2009). Stevardiinae as proposed by Weitzman et al. (2005) include the tribes Landonini, Diapomini, Phenacobryconini, Hysteronotini, Corynopomini, and Xenurobryconini. According to Weitzman et al. (2005), the Stevardiinae can be separated from the Glandulocaudinae by three characters: 1 ) presence in the Stevardiinae and in the genus Knodus of a hypertrophic extension of the body scales onto the rays of ventral caudal-fin lobe which is absent in all Glandulocaudinae; 2) caudal organs of the species of the
Glandulocaudinae with a hypertrophic extension of the upper lobe body scales onto the rays of the dorsal caudalfin lobe rather than the lower caudal-fin lobe as in the Stevardiinae tribes; and 3) caudal-gland cells of the caudal organ of the Glandulocaudinae consisting of apparently specialized club cells, not the modified mucous cells reported for some Stevardiinae.

Based mainly on the analysis of osteological characters Mirande (2010) proposed a new phylogenetic arrangement for members of the Characidae and considered the Stevardiinae a more inclusive group composed of all the genera belonging to Clade A of Malabarba \& Weitzman (2003), plus the genera Aulixidens, Bryconadenos, and Nantis. According to this phylogenetic arrangement the Glandulocaudinae and Stevardiinae of Weitzman et al. (2005) and Menezes \& Weitzman (2009) would have to be considered subgroups within Mirande's Stevardiinae.

\footnotetext{
${ }^{1}$ Museu de Zoologia da Universidade de São Paulo, Laboratório de Ictiologia. Av. Nazaré, 481, Ipiranga, 04263-000 São Paulo, SP, Brazil. katiane@usp.br, naercio@usp.br

${ }^{2}$ Universidade Estadual Paulista, Instituto de Biociências, Departamento de Morfologia. Cx. Postal 510, $18618-000$ Botucatu, SP, Brazil. iraniqg@ibb.unesp.br
} 
Examination of material at MZUSP, MCP, MNRJ, and LIRP collections revealed the presence of two undescribed species belonging to a new genus of the Stevardiinae (see Fig. 1 in Results). One of them was collected only in the rio Pratinha and rio Santo Antônio along the eastern Brazilian coast. The other was collected in several tributaries of the upper rio São Francisco. In this paper, we describe these two recently discovered species and also briefly discuss their phylogenetic relationships within the Stevardiinae based on osteological and histological characters.

\section{Material and Methods}

\section{Phylogenetic procedures}

Hypotheses on relationships were proposed using the cladistic method. The parsimony analysis was employed using TNT software (Goloboff et al., 2003). The traditional search with 2000 replicates and implied weighting $(\mathrm{k}=3)$ was applied. Character state distribution was examined using ACCTRAN optimization. The data set consists of 33 species represented by as many species as possible of all recognized genera of the Stevardiinae, based on availability of specimens for clearing and staining and histological analyses. Most members of Clade A characids of Malabarba \& Weitzman (2003) were chosen as outgroups. The analyses were rooted in Tetragonopterus argenteus, a Characidae incertae sedis basal member.

The data matrix was assembled with the aid of NDE 0.5.0 (Page, 2001) for Windows with all characters coded as unordered.

Characters are defined and described in Appendix 1 below and the matrix is presented in Appendix 2. Missing entries in the data matrix are represented by '?' when the character state could not be evaluated due to lack of appropriate study material or as a consequence of the impossibility of coding the state for that taxon, or represented by '-' for inapplicable character states.

\section{Osteological preparations}

The cleared and staining protocol used follows the method of Taylor \& van Dyke (1985). Whenever possible, two or more specimens of each species were prepared in that fashion in order to facilitate checking anomalous features and also to allow for evaluation, whenever possible, of sexually dimorphic osteological features. Osteological terminology follows Weitzman (1962) with the modifications listed by Vari \& Harold (2001).

\section{Electronic microscopic preparations}

Transmission Electron Microscope (TEM). Gonads used were extracted from specimens previously fixed in formalin solution $10 \%$ and preserved in alcohol $70^{\circ}$ GL kept in ichthyological collections. Fragments of gonads were posfixed for $48 \mathrm{~h}$ in solutions of $2 \%$ glutaraldehyde and $4 \%$ paraformaldehyde in $0.1 \mathrm{M}$ Sorensen phosphate buffer, $\mathrm{pH}$ 7.4. The material was post-fixed again for $2 \mathrm{~h}$ in the dark in
$1 \%$ osmium tetroxide in the same buffer, stained in block with an aqueous solution of 5\% uranyl acetate for $2 \mathrm{~h}$, dehydrated in acetone, embedded in araldite, and sectioned and stained with a saturated solution of uranyl acetate in $50 \%$ ethanol, and with lead citrate (Reynolds, 1963). Electromicrographs were obtained using a Phillips - CM 100 transmission electron microscope.

Scanning Electron Microscope (SEM). Head and caudal-fin of all species included in this study were submitted to SEM. All specimens were fixed in formalin solution $10 \%$ and conserved in alcohol $70^{\circ} \mathrm{GL}$. After that, the material was dehydrated in graded ethanols, dried at the critical point with liquid $\mathrm{CO}_{2}$, sputtered with gold and examined with a LEO Electron Microscope.

Light microscopy preparations. Tissues of gills, ovaries, testes and all fins from all species were used. The specimens were initially fixed in $10 \%$ formalin and subsequently transferred to $70 \%$ ethanol. Fin and gill tissues were decalcified in hydrochloric acid and alcohol $70 \%$, for 12 days. The tissues were hydrated again for $5 \mathrm{~h}$, and post-fixed overnight in $2 \%$ glutaraldehyde and 4\% paraformoldehyde in $0.1 \mathrm{M}$ Sorensen phosphate buffer, $\mathrm{pH} 7.2$ and then dehydrated in an ethanol series, embedded in methacrylate, sectioned at $3 \mu \mathrm{m}$ and stained with Hematoxylin and Eosin and Toluide Blue $\mathrm{pH}$ alkaline.

\section{Taxonomy}

Counts and measurements follow Fink \& Weitzman (1974) except for counts of the horizontal scale rows below the lateral line, counted from pelvic-fin origin to lateral line. In the tables and elsewhere in the text, standard length (SL) is expressed in $\mathrm{mm}$ and all other measurements are expressed as percents of SL, except for subunits of the head, expressed as percents of head length (HL). Counts are included in the description, followed by frequency of particular values in parentheses. Asterisks indicate values of the holotype. In the diagnosis, the mode is presented between square brackets. Counts of vertebrae and supraneurals were taken from cleared and stained (c\&s) paratypes. Counts of total vertebral include the four vertebrae of the Weberian apparatus and the terminal half centrum. Number and size range of measured specimens in each lot is given in parentheses."

\section{Institutional abbreviations}

Abbreviations for institutions and collections are as follows: CPUFMT, Coleção de Peixes da Universidade Federal do Mato Grosso, Cuiabá; MZUSP, Museu de Zoologia da Universidade de São Paulo, São Paulo; MNRJ, Museu Nacional, Universidade Federal do Rio de Janeiro, Rio de Janeiro; MCP, Museu de Ciências e Tecnologia, Pontifícia Universidade Católica do Rio Grande do Sul, Porto Alegre; LIRP, Laboratório de Ictiologia de Ribeirão Preto, Universidade de São Paulo, Ribeirão Preto; MUSM, Museo de Historia Natural de la Universidad Mayor de San Marcos, Lima. 


\section{Results}

\section{Phylogenetic reconstruction}

Our analysis of phylogenetic relationships within Lepidocharax was based on 153 osteological and histological characters and 33 terminal taxa. Analysis utilizing TNT resulted in one three with 754 steps, with a consistency index (CI) of 0.32 and retention index (RI) of 0.58 (Fig. 1). Numbers in Fig. 1 indicate clades discussed in the following sections.

\section{Lepidocharax, new genus}

Type species. Lepidocharax diamantina, by original designation.

Diagnosis. According to our analysis, Lepidocharax can be phylogenetically diagnosed from the remaining Stevardiinae by the presence of the following autapomorphies supporting clade $4: 1)$ parhypural and hypural 1 either contacting each other leaving a narrow joint line between them or fused to each other (character 64, state 1), and 2) nasal tubular, without bone expansion (character 96, state 1). Both characters are, however, homoplastically shared among other Stevardiinae. Character 64 (state1) also supports clades 10 and 13, and character 96 (state 1) supports clade 16.

In addition, several distinguishing features are useful to diagnose Lepidocharax. It can be distinguished from all the other genera of the Stevardiinae except Planaltina, Pseudocorynopoma, and Xenurobrycon by having the dorsal- fin origin on the same vertical crossing the anal-fin origin. The presence of adnate scales over the ventral caudal-fin lobe distinguishes Lepidocharax from Planaltina, Pseudocorynopoma, and Xenurobrycon which have a caudal organ or pouch bordered by modified scales or represented by a single modified pouch scale.

Etymology. Lepido, from the Greek, for scales and charax ,from the Greek characo, meaning pointed stake, here used in reference to the characid genus Charax, hence a Characid fish. Lepidocharax is a name used in reference to the scales covering the ventral caudal-fin lobe. A noun in apposition.

\section{Lepidocharax diamantina, new species}

Figs. 2-5

Holotype. MNRJ 37509, 38.8 mm SL, male, Brazil, Bahia, Palmeiras, rio Santo Antônio, a tributary to rio Paraguaçu, approx. $12^{\circ} 31^{\prime}$ S $41^{\circ} 34^{\prime} \mathrm{W}, 12$ Mar 1999, A. Clistenes.

Paratypes. MNRJ 21997, 55, 19.8-38.2 mm SL (20, 25.1-38.9 mm SL), (1 c\&s, $34.7 \mathrm{~mm} \mathrm{SL}$ ), collected with holotype; MZUSP 106499 , 9, 33.3-37.8 mm SL, Brazil, Bahia, Iraquara, rio Pratinha, at fazenda Pratinha, 12²1'13"S 4132'51'W, 17-21 Dec 1998, P. Gerhard, F. C. T. Lima, F. Di Dário \& L. S. Rocha.

Diagnosis. Lepidocharax diamantina can be distinguished from Lepidocharax burnsi by having the head less deep (16.718.8 vs. $18.7-25.0 \%$ SL), by having more longitudinal scale

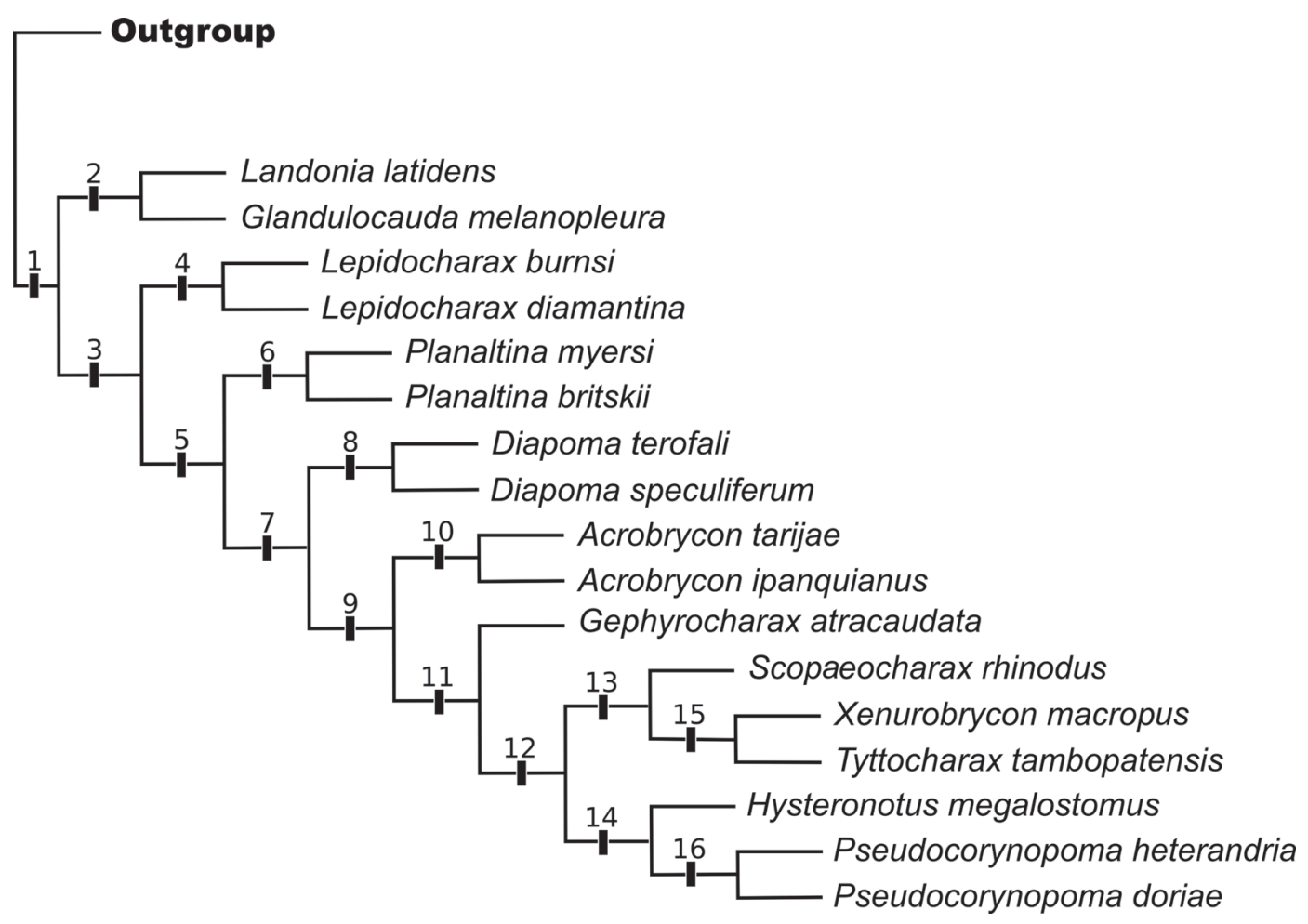

Fig. 1. Maximally parsimonious hypothesis of relationships within the Lepidocharax based on 153 characters. 


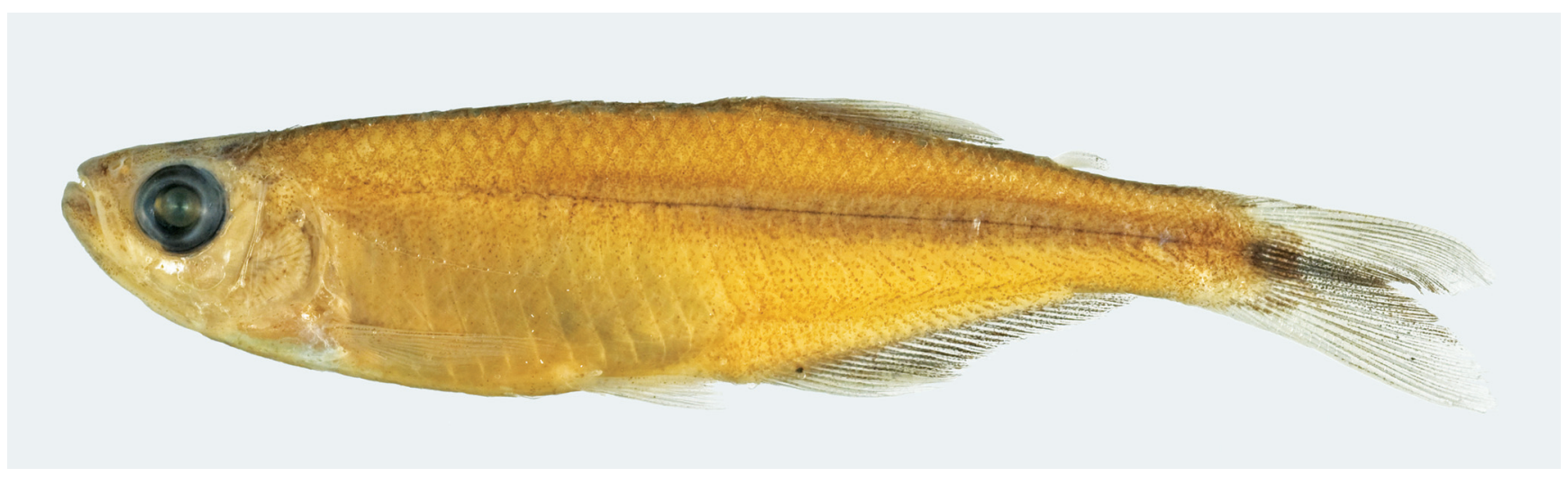

Fig. 2. Lepidocharax diamantina, holotype, male, MNRJ 37509, 38.8 mm SL: Brazil, Bahia, Palmeiras, rio Santo Antônio.

rows between the lateral-line and the pelvic-fin origin ( 8 vs. 67); more lateral-line scales (47-56 [54] vs. 39-46 [41]); and less branched anal-fin rays (19-22 [22] vs. 21-26 [23]).

Description. Morphometric and meristic data for holotype and paratypes presented in Table 1.

Body laterally compressed, moderately elongate, largest specimen $38.8 \mathrm{~mm}$ SL. Greatest body depth situated at dorsalfin origin. Dorsal profile of head slightly convex from margin of upper lip to tip of supraoccipital spine; slightly convex from tip of supraoccipital spine to dorsal-fin origin; straight along dorsal-fin base; straight from posterior terminus of dorsal-fin base to adipose-fin insertion, and slightly concave from latter point to caudal-fin origin. Ventral profile of body convex from tip of lower jaw to anal-fin insertion and slightly concave ventral to caudal peduncle; anal-fin base straight.

Dorsal-fin rays ii, $8 *(25)$ or 9(4). Length of first unbranched dorsal-fin ray less than one-half length of second unbranched ray. Adipose fin present, its origin located vertically above bases of last three anal-fin rays. Pectoral-fin rays i, $9 *(18)$ or 10(11),i. Pelvic-fin rays i,5,i*(29). Anal fin with four unbranched rays followed by 19(1), 20(10), 21(6)* or 22(12) branched rays. Sexually mature males with hooks on anal-and pelvic-fin rays. Anal-fin hooks very small and located on segments from largest unbranched to $10^{\text {th }}$ branched ray (Fig. 3). Usually, 1013 hooks per ray. Pelvic-fin hooks also numerous and small, and present on segments of all branched rays. Caudal-fin forked; lobes similar in size. Principal caudal-fin rays i,17,i*(29).

Premaxilla extending slightly anterior of vertical through tip of dentary. Premaxilla with two rows of teeth (Fig. 4). Outer tooth row aligned in gentle arch, with 3(3), $4 *(24)$ or 5(2) tricuspid teeth, with median cusps largest. Inner premaxillary tooth row with $4(21)$ or $5^{*}(8)$ teeth. Symphyseal tooth in row with four cusps and remaining teeth with five cusps. Maxilla with $2 *(3)$, $3(21)$ or 4(3) tricuspid teeth with median cusps slightly more developed. Dentary with four large anterior teeth with five cusps followed by smaller teeth with three to five cusps.

Scales cycloid. Lateral line complete, with 48(1), 49(2), 50(2), 51(2), 52(4), 53(4), 54*(6), 55(3), or 56(3) perforated scales. Eight longitudinal rows of scales between dorsal-fin origin and lateral line, $4 *(17)$ or $5(12)$ between lateral line and pelvic- fin origin. Predorsal scales 19(4), 20*(8), 21(8), or 22(8). Circumpeduncular scales 15-21. Single row of five to seven scales extending along anal-fin base. Basal portion of both caudal-fin lobes covered by medium size scales, about same

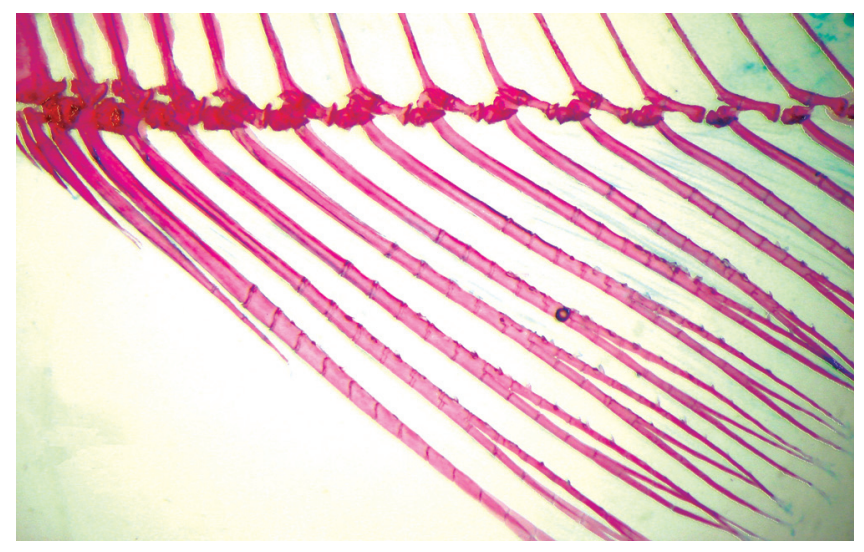

Fig. 3. Hooks on anal-fin rays of Lepidocharax diamantina, MNRJ 21997, paratypes, $38.0 \mathrm{~mm} \mathrm{SL}$, adult male.

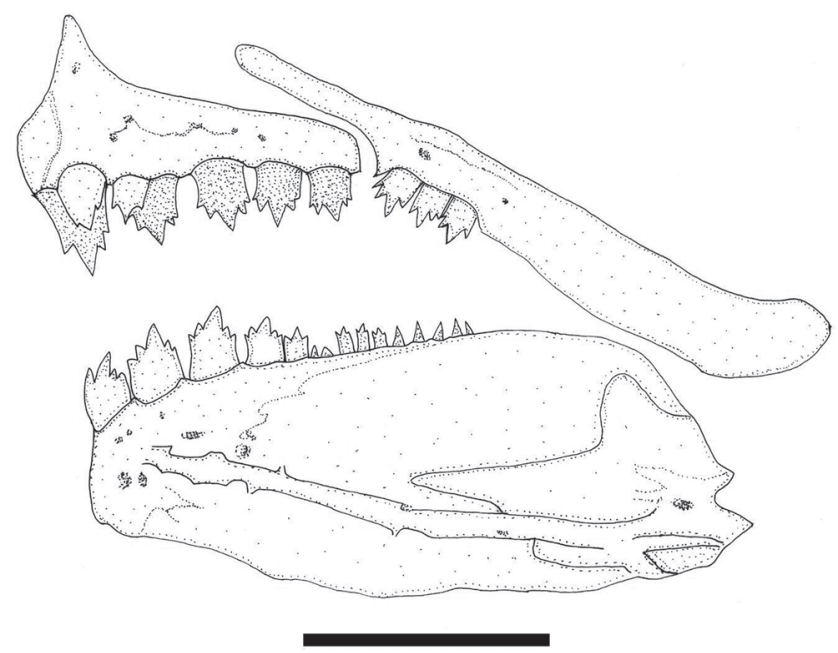

Fig. 4. Lepidocharax diamantina, MNRJ 21997, paratypes, $38.0 \mathrm{~mm}$ SL. Upper and lower jaws, left side, lateral view. Scale bar $=1 \mathrm{~mm}$. 
size as those present on caudal peduncle (Fig. 5).

First gill arch with 10(3), 11(15), or 12*(8) gill rakers on hypobranchial and ceratobranchial, 6(23) or $7 *(6)$ rakers on epibranchial and $1 *(23)$ raker on cartilage between ceratobranchial and epibranchial.

Color in alcohol. Head and body of specimens retaining guanine on scales, therefore somewhat silvery. Overall ground coloration yellowish tan. Dorsal surface of head and lips with dense concentration of dark chromatophores. Scattered dark chromatophores covering only upper region of opercle, in fourth to sixth infraorbitals. Dark chromatophores concentrated on predorsal scales. Concentration of chromatophores decreasing progressively from middorsal region to lateral line, where limited to edges of scales. Chromatophores absent in scales of abdominal region below lateral line. Chromatophores present between lateral

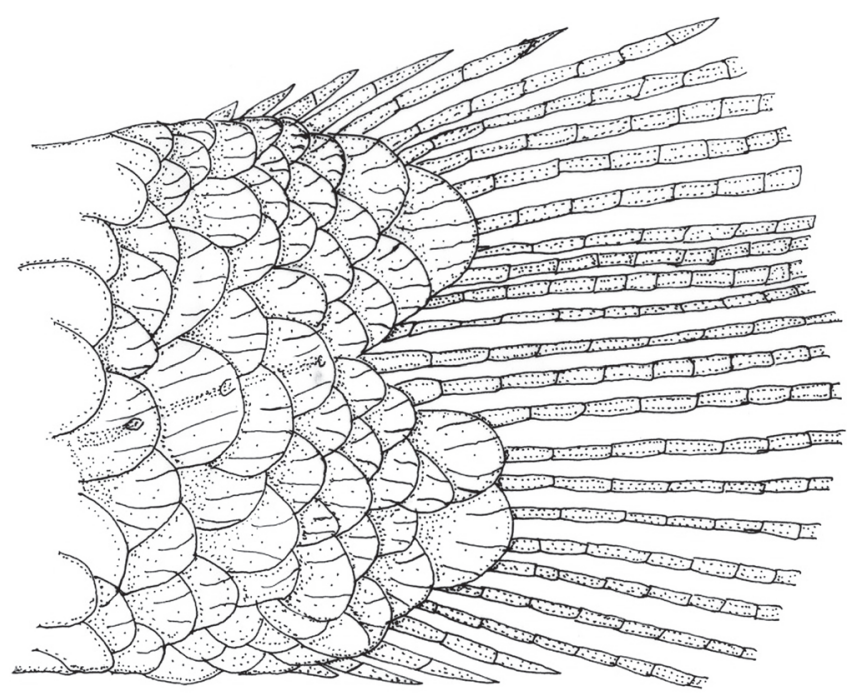

Fig. 5. Lepidocharax diamantina, MNRJ 21997, paratypes, male, $32.3 \mathrm{~mm}$ SL. Caudal-fin squamation, lateral view, left side. line and anal fin. Midlateral stripe on body extending from behind upper part of opercle to caudal peduncle. Dorsal, pectoral, pelvic, and caudal fins hyaline, with scattered dark chromatophores outlining rays and forming straight lines. Dark chromatophores concentrated along distal borders of interradial membranes of anal-fin base. Adipose fin pale, with small, dark chromatophores concentrated on posterior base of fin.

Distribution. Lepidocharax diamantina is known from the rio Paraguaçu basin, an independent costal river system in Bahia State, northeastern Brazil (Fig. 6).

Etymology. Named after the Chapada Diamantina, the region where the species is found. Iraquara and Palmeiras where Lepidocharax diamantina was sampled are two of the 24 villages located in Chapada Diamantina. A noun in apposition.

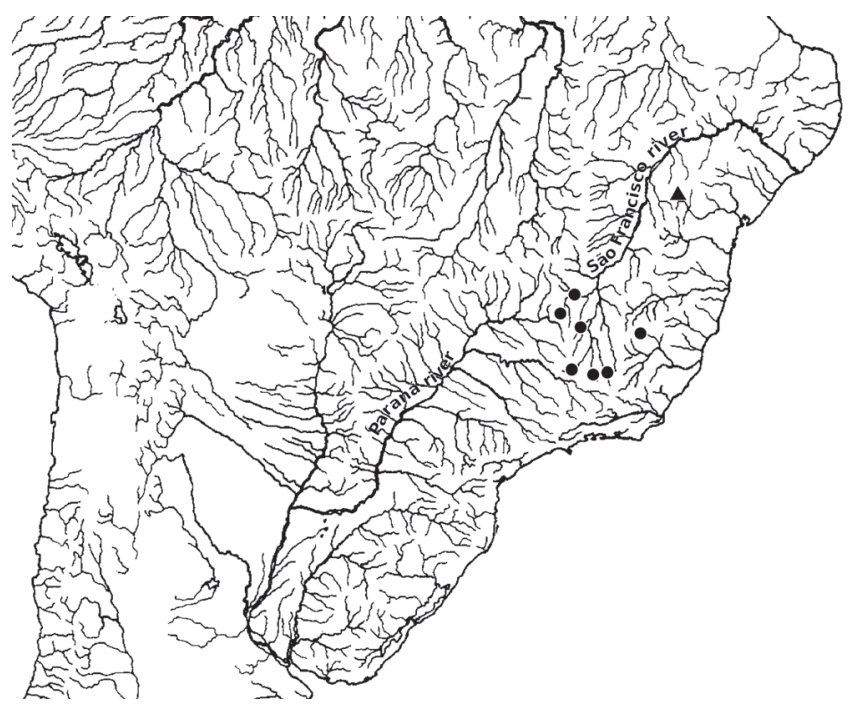

Fig. 6. Distribution of Lepidocharax; triangle: L. diamantina; circle: L. burnsi.

Table 1. Morphometric data of Lepidocharax diamantina $(\mathrm{n}=30$, including the holotype), $p$ is significant when $<0.05$. $\mathrm{SD}=$ standard deviation.

\begin{tabular}{|c|c|c|c|c|c|c|c|c|}
\hline & Holotype & Paratypes & & & & & & \\
\hline & & $\begin{array}{l}\text { Males } \\
\text { range }\end{array}$ & mean & $S D$ & $\begin{array}{l}\text { Females } \\
\text { range }\end{array}$ & mean & $S D$ & $p$ \\
\hline Standard length (mm) & \multicolumn{7}{|c|}{ Percents of Standard length } & - \\
\hline Body depth & 24.2 & $21.3-24.6$ & 22.7 & 0.9 & $20.0-23.6$ & 22.3 & 1.1 & 0.48 \\
\hline Head length & 23.3 & $21.2-23.6$ & 22.5 & 0.6 & $21.7-23.7$ & 22.6 & 0.6 & 0.43 \\
\hline Head depth & 17.8 & $16.7-18.7$ & 17.8 & 0.5 & $17.2-18.8$ & 17.8 & 0.5 & 0.48 \\
\hline Snout to dorsal-fin origin & 58.5 & $57.3-61.3$ & 58.7 & 0.9 & $57.2-61.5$ & 59.0 & 1.2 & 0.42 \\
\hline Snout to pelvic-fin origin & 45.9 & $44.2-46.6$ & 45.3 & 0.7 & $44.4-47.4$ & 45.5 & 0.8 & 0.43 \\
\hline Pelvic-fin insertion to anal-fin origin & 14.6 & $12.8-16.2$ & 14.6 & 1.0 & $14.6-16.4$ & 15.2 & 0.5 & 0.37 \\
\hline Caudal peduncle length & 8.8 & $7.5-9.3$ & 8.5 & 0.6 & $6.4-8.6$ & 7.8 & 0.6 & 0.66 \\
\hline Dorsal-fin length & 11.3 & $9.7-12.3$ & 11.1 & 0.7 & $9.5-12.5$ & 10.3 & 0.8 & 0.92 \\
\hline Anal-fin length & 29.6 & $26.3-30.1$ & 27.6 & 1.1 & $26.7-29.4$ & 27.6 & 0.9 & 0.44 \\
\hline Length of longest pectoral-fin ray & 21.1 & $19.9-22.8$ & 21.1 & 0.8 & $19.7-21.2$ & 20.5 & 0.4 & 0.51 \\
\hline Length of longest pelvic-fin ray & 14.5 & $12.0-15.1$ & 13.9 & 0.8 & $11.8-13.7$ & 12.8 & 0.6 & 0.66 \\
\hline Length of longest dorsal-fin ray & 21.3 & $16.7-22.5$ & 20.2 & 1.3 & $11.5-19.9$ & 18.0 & 2.2 & 0.70 \\
\hline Length of longest anal-fin ray & 17.5 & $14.7-18.6$ & 16.6 & 1.0 & $15.2-17.1$ & 16.2 & 0.6 & 0.55 \\
\hline \multicolumn{9}{|c|}{ Percents of Head length } \\
\hline Orbital diameter & 34.6 & $34.5-38.4$ & 36.0 & 1.1 & $34.8-39.3$ & 36.3 & 1.4 & 0.52 \\
\hline Snout length & 25.5 & $22.1-27.1$ & 25.2 & 1.2 & $22.8-26.3$ & 24.7 & 0.9 & 0.54 \\
\hline Interorbital width & 34.1 & $31.3-36.1$ & 33.4 & 1.4 & $32.0-35.0$ & 33.2 & 0.8 & 0.52 \\
\hline
\end{tabular}




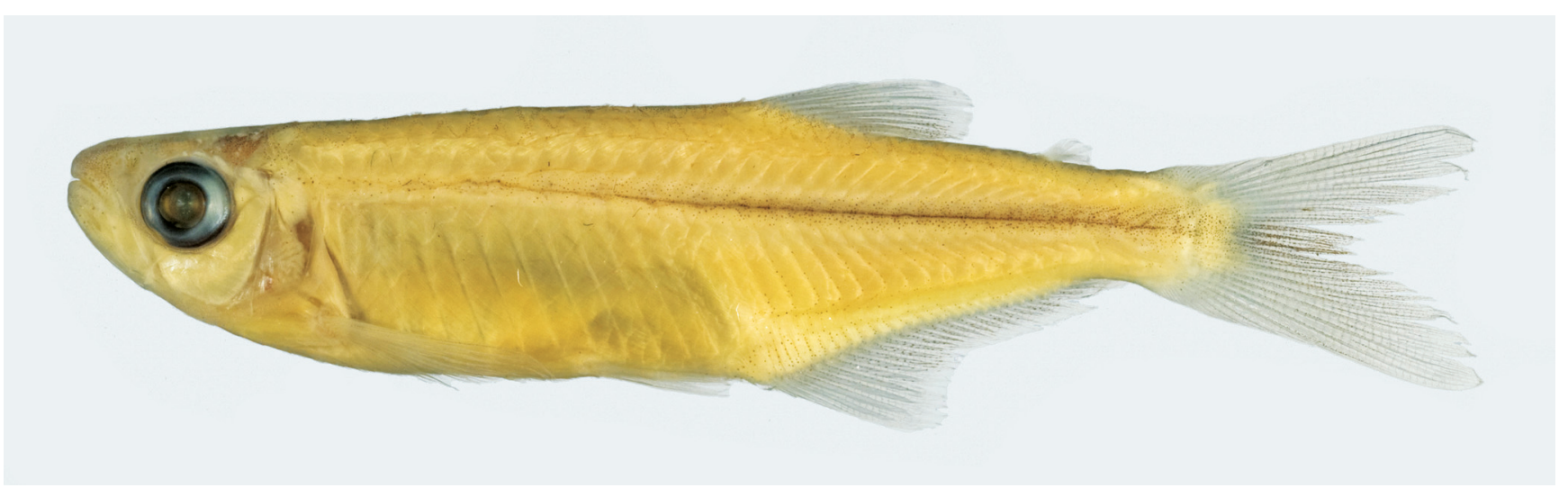

Fig. 7. Lepidocharax burnsi, holotype, female, MCP 45718, $34.4 \mathrm{~mm} \mathrm{SL:} \mathrm{Brazil,} \mathrm{Minas} \mathrm{Gerais,} \mathrm{Brumadinho,} \mathrm{rio} \mathrm{Paraopeba.}$

\section{Lepidocharax burnsi, new species}

Fig. 7

Holotype. MCP 45718, 34.4 mm SL, female, Brazil, Brumadinho, rio Paraopeba, São Francisco basin, approx. 2009'S 44¹0”'W, Apr 1997, V. Vono \& C. B. M. Alves.

Paratypes. All from Brazil, Minas Gerais, São Francisco basin: CPUFMT 31, 16, 19.2-25.9 mm SL (2, 19.1-26.8 mm SL), Riachinho, rio Urucuia, córrego Santa Cruz, 16²7'16”S 4547'22'W, $10 \mathrm{Apr}$ 2009, A. C. Ribeiro. LIRP 2069, 16, 26.8-33.8 (6, 30.1-33.8 mm SL), Presidente Olegário, upper rio da Prata, córrego São João, fazenda Devaneio, $18^{\circ} 23^{\prime}$ 'S $46^{\circ} 16^{\prime \prime W}, 14$ Oct 2000, A. C. Ribeiro. LIRP 4160, 147, 19.2-33.3 mm SL (17, 26.3-33.5 mm SL), Felixlândia, córrego do Brito, 27 Jan 2002, A. Melo. MCP 27824, 1, 30.2 mm SL, Paracatu, 17¹8'15"S 4646'16”W, 24 Jan 2001, C. Lucena, J. Silva, E. Pereira \& A. Cardoso. MCP 27829, 128, 20.2$32.2 \mathrm{~mm}$ SL (17, 22.6-32.2 mm SL), Guarda-Mor, rio Piratininga, 1756'39'S 46058'08'W, 25 Jan 2001, C. Lucena, J. Silva, E. Pereira \& A. Cardoso. MCP 31798, 1, 29.7 mm SL, collected with holotype; MCP 34684, 2, 26.0-28.3 mm SL, córrego São Miguel, 20¹2'00”'S 45³9'09'W, 26 Sep 2003, B. P. Nogueira. MCP 34828, 24, 21.432.4 mm SL (15, 22.6-32.5 mm SL), Guarda-Mor, córrego Macaúba, $17^{\circ} 58^{\prime}$ '57'S 4706'41'W, 24 Jan 2001, C. Lucena, J. Silva, E. Pereira \& A. Cardoso; MZUSP 39190, 31, 19.3-29.3 mm SL (2, 28.5-29.3 mm SL), córrego Gameleira, 27 Nov 1987, Y. Sato, UHE Formoso project. MZUSP 39651, 4, 32.3-39.9 mm SL (3, 35.7-39.9 mm SL), rio Abaeté, córrego Chumbo, 18 Mar 1988, Y. Sato, UHE Formoso project.

Non-type specimens. MCP 27915, 36, 20.2-32.8 mm SL (16, 22.6-31.9 $\mathrm{mm} \mathrm{SL}$ ), rio Vermelho, rio Doce basin, $18^{\circ} 17^{\prime} \mathrm{S}$ $43^{\circ} 01^{\prime}$ W, 5 Oct 1996, H. G. Evers.

Diagnosis. Lepidocharax burnsi can be distinguished from L. diamantina by its deeper head (18.7-25.0 vs. $16.7-18.8 \%$ SL); by possessing fewer longitudinal scale rows between the lateral-line and the pelvic-fin origin (6-7 vs. 8); fewer lateralline scales (39-46 [41] vs. 47-56 [54]); and more branched analfin rays $(21-26$ [23] vs. 19-22 [22]).

Description. Morphometric and meristic data for holotype and paratypes presented in Table 2.
Body laterally compressed, moderately elongate, largest specimen $38.8 \mathrm{~mm}$ SL. Greatest body depth situated at dorsalfin origin. Dorsal profile of head slightly convex from margin of upper lip to tip of supraoccipital spine; slightly convex from tip of supraoccipital spine to dorsal-fin origin; straight along dorsal-fin base; straight from posterior terminus of dorsal-fin base to adipose-fin insertion, and slightly concave from latter point to caudal-fin origin. Ventral profile of body convex from tip of lower jaw to anal-fin insertion and slightly concave ventral to caudal peduncle; anal-fin base straight.

Dorsal-fin rays ii,7(1) or 8*(51). Length of first unbranched dorsal-fin ray less than one-half length of second unbranched ray. Adipose fin present. Length of adipose fin base in a vertical above bases of last three anal-fin rays. Pectoral-fin rays i,8(4), $9^{*}(44)$ or 10(3),i. Pelvic fin rays i,5,i*(52). Anal fin with four unbranched rays followed by 21(2), 22(8), 23*(17), 24(16), 25(5), or 26(2) branched rays. Sexually mature males with hooks on anal-and pelvic-fin rays. On anal-fin, hooks are very small and located on segments from largest unbranched ray until de 10$13^{\text {th }}$ branched ray (Fig. 8). Usually, there are three hooks per ray. On pelvic-fin, hooks also are numerous and small, and present on segments of all branched rays. Caudal-fin forked; lobes similar in size. Principal caudal-fin rays i, 17, $i^{*}(52)$.

Premaxilla extending slightly anterior of vertical through tip of dentary. Premaxilla with two rows of teeth (Fig. 9). Outer tooth row aligned in gentle arch, with 3(2) or $4 *(48)$ tricuspid teeth, with median cusps largest. Inner premaxillary tooth row with 4(34) or $5 *(14)$ teeth. Symphyseal tooth in row with four cusps and remaining teeth with five cusps. Maxilla with $2 *(40)$,

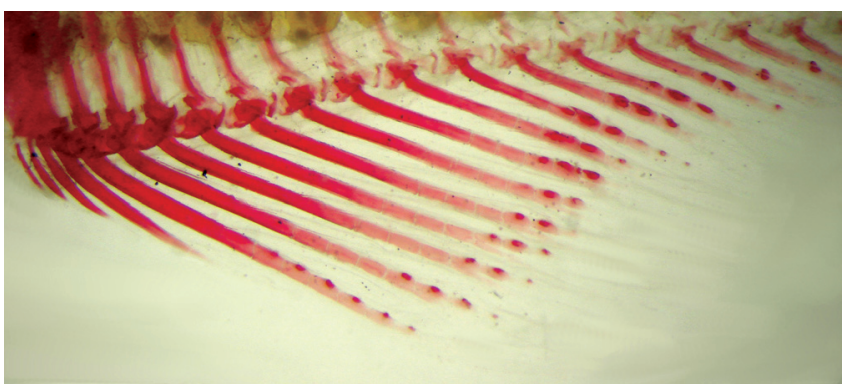

Fig. 8. Hooks on anal-fin rays of Lepidocharax burnsi, LIRP 2069, paratype, $34.0 \mathrm{~mm} \mathrm{SL}$, adult male. 
Table 2. Morphometric data of Lepidocharax burnsi $(\mathrm{n}=82), p$ is significant when $<0.05$. $\mathrm{SD}=$ standard deviation.

\begin{tabular}{|c|c|c|c|c|c|c|c|c|c|c|c|c|c|c|}
\hline & \multirow[t]{3}{*}{ Holotype } & \multicolumn{7}{|c|}{ Paratypes $(n=65)$} & \multicolumn{6}{|c|}{ Non-type material $(n=16)$} \\
\hline & & \multicolumn{2}{|c|}{ Males } & \multicolumn{3}{|c|}{ Females } & \multirow[b]{2}{*}{$S D$} & \multirow[b]{2}{*}{$p$} & \multicolumn{3}{|c|}{ Males } & \multicolumn{3}{|c|}{ Females } \\
\hline & & range & mean & $S D$ & range & mean & & & range & mean & $S D$ & range & mean & $S D$ \\
\hline$\overline{\text { Standard length }(\mathrm{mm})}$ & 34.4 & $24.1-32.1$ & 29.3 & - & $22.6-34.4$ & 27.9 & - & - & $25.5-31.9$ & 28.7 & - & $22.6-34.4$ & 27.2 & - \\
\hline \multicolumn{15}{|c|}{ Percents of Standard length } \\
\hline Body depth & 25.6 & $23.8-28.3$ & 25.8 & 1.2 & $21.5-28.2$ & 24.1 & 1.4 & 0.33 & $23.8-25.5$ & 24.7 & 0.9 & $22.5-25.6$ & 23.9 & 1.0 \\
\hline Head & 23.0 & $19.7-25.5$ & 24.1 & 1.3 & $23.2-25.8$ & 24.7 & 0.8 & 0.32 & $24.4-24.5$ & 24.5 & 0 & $23.0-25.2$ & 24.1 & 0.6 \\
\hline Head depth & 20.0 & $9.3-22.6$ & 20.4 & 0.7 & $18.7-25.0$ & 20.2 & 0.7 & 0.34 & $19.8-20.1$ & 19.9 & 0.2 & $19.1-20.6$ & 19.7 & 0.5 \\
\hline Snou & 58.5 & $.1-62.4$ & 59.8 & 1.2 & $56.3-61.9$ & 59.4 & 1.5 & 1.00 & $59.2-59.3$ & 59.3 & 0.1 & $56.8-60.5$ & 58.5 & 1.0 \\
\hline Snc & 46.3 & 9.0 & 47.4 & 1.0 & $42.6-49.9$ & 46.5 & 1.3 & 0.38 & $46.1-46.6$ & 46.4 & 0.2 & $45.0-47.2$ & 45.8 & 0.7 \\
\hline Pel & 16.0 & 4.8 & 13.1 & 0.8 & $8.1-16.6$ & 14.6 & 1.6 & 1.00 & -14.7 & 14.6 & 0.2 & $14.1-16.7$ & 15.5 & 0.7 \\
\hline $\mathrm{Cau}$ & 8.9 & 10.3 & 9.4 & 0.7 & $7.9-9.3$ & 8.3 & 0.4 & 0.19 & $8.7-9.6$ & 9.2 & 0.4 & $8.0-8.9$ & 8.4 & 0.3 \\
\hline Dor & 9.6 & $9.2-11.6$ & 10.4 & 0.6 & $9.1-11.2$ & 9.8 & 0.6 & 0.15 & $9.7-10.9$ & 10.3 & 0.6 & $9.2-10.9$ & 9.9 & 0.6 \\
\hline Anal- & 28.8 & $8.0-33.0$ & 30.7 & 1.3 & $26.2-33.0$ & 28.7 & 1.6 & 0.19 & $29.4-30.2$ & 29.8 & 0.4 & $26.5-29.9$ & 28.2 & 1.1 \\
\hline Lengt & 22.5 & $18.8-25.1$ & 22.2 & 1.3 & $17.8-22.5$ & 21.2 & 1.1 & 0.21 & $21.6-22.0$ & 21.8 & 0.2 & $20.3-22.5$ & 21.6 & 0.6 \\
\hline Lengt & 14.1 & $11.6-18.8$ & 13.8 & 1.5 & $11.0-14.6$ & 12.9 & 0.9 & 0.18 & $13.3-14.6$ & 14.0 & 0.6 & $12.7-14.6$ & 13.6 & 0.6 \\
\hline dorsal-fin ray & 18.7 & $17.0-21.4$ & 19.3 & 1.0 & $15.5-20.7$ & 18.2 & 1.1 & 0.21 & $19.3-20.1$ & 19.7 & 0.4 & $17.6-20.7$ & 19.1 & 0.9 \\
\hline Length of longest anal-fin ray & 16.0 & $13.6-17.7$ & 15.9 & 1.0 & $13.9-17.8$ & 15.6 & 0.9 & 0.52 & $16.8-16.9$ & 16.8 & 0 & $13.8-17.3$ & 15.9 & 0.9 \\
\hline \multicolumn{15}{|c|}{ Percents of Head length } \\
\hline Orb & 36.8 & $5-44.4$ & 38.9 & 2.1 & $36.7-41.6$ & 39.2 & 1.6 & 0.46 & 8.5 & 37.6 & 0.9 & $36.8-41.3$ & 38.5 & 1.6 \\
\hline Snout & 25.6 & $23.0-30.8$ & 25.6 & 1.7 & $21.4-26.8$ & 24.1 & 1.5 & 0.33 & $23.1-25.8$ & 24.4 & 1.4 & $21.5-26.7$ & 24.4 & 1.6 \\
\hline Interorbital width & 35.7 & $31.9-42.6$ & 34.7 & 2.2 & $31.9-36.7$ & 33.5 & 1.3 & 0.32 & $34.0-35.7$ & 34.9 & 0.8 & $32.6-36.5$ & 34.4 & 0.5 \\
\hline
\end{tabular}

3(9) or 4(2) tricuspid teeth with median cusps slightly more developed. Dentary with four large anterior teeth with five cusps followed by smaller teeth with three to five cusps.

Scales cycloid. Lateral line complete, with 39(1), 40(13), $41 *(16), 42(12), 43(4), 44(3), 45(1)$, or 46(1) perforated scales. Six*(43), or 7(8) longitudinal scale rows between dorsal-fin origin and lateral line four*(27) or 5(24) between lateral line and pelvic-fin origin. Predorsal scales 14(1), 15(7), 16*(18), 17(18), 18(6), or 19(1). Circumpeduncular longitudinal scale rows 14-18. Single row of seven to ten scales extending along base of anal fin. Basal portion of both caudal-fin lobes covered with medium size scales, about as large as scales on caudal peduncle (Fig. 10).

First gill arch with 9(2), 10(28), or $11 *(21)$ gill rakers on hypobranchial and ceratobranchial, $5(8)^{*}, 6(41)$, or $7(2)$, rakers on epibranchial and 1 raker on cartilage between ceratobranchial and epibranchial.

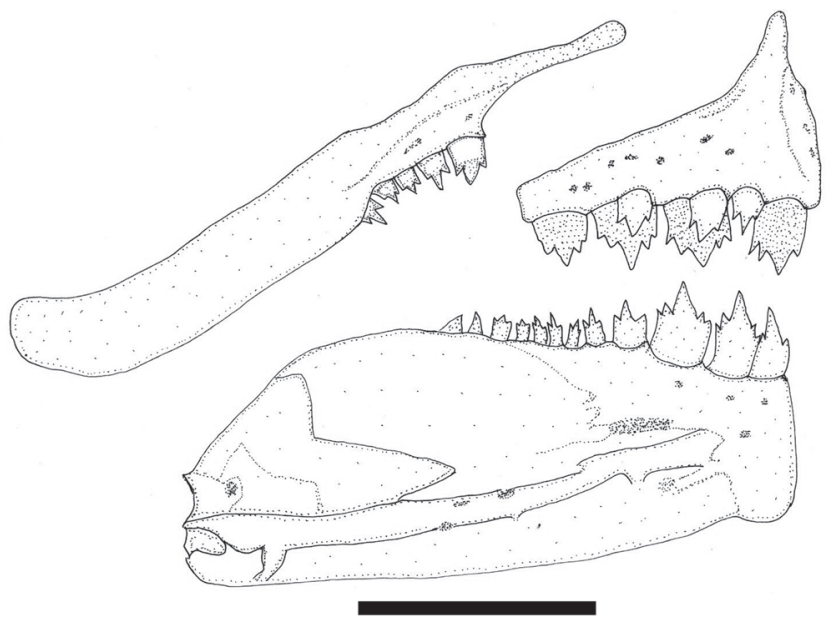

Fig. 9. Lepidocharax burnsi, LIRP 2069, paratype, $34.0 \mathrm{~mm}$ $\mathrm{SL}$, adult male. Upper and lower jaws, right side, lateral view. Scale bar $=1 \mathrm{~mm}$.
Color in alcohol. Head and body of specimens retaining guanine on scales, therefore somewhat silvery. Overall ground coloration yellowish tan. Dorsal surface of head and lips with dense concentration of dark chromatophores. Scattered dark chromatophores covering only upper region of opercle. Dark chromatophores concentrated on predorsal scales. Concentration of chromatophores decreasing progressively from middorsal region to lateral line, where limited to edges of scales. Chromatophores absent on scales of abdominal region below lateral line. Chromatophores present between lateral line and anal fin. Midlateral stripe on body extending from behind upper part of opercle to caudal peduncle. Dorsal, pectoral, pelvic, and caudal fins hyaline, with scattered dark chromatophores outlining rays and forming straight lines. Dark chromatophores concentrated along distal borders of interradial membranes of anal fin base. Adipose fin clear, with small, dark chromatophores concentrated on posterior base of fin.

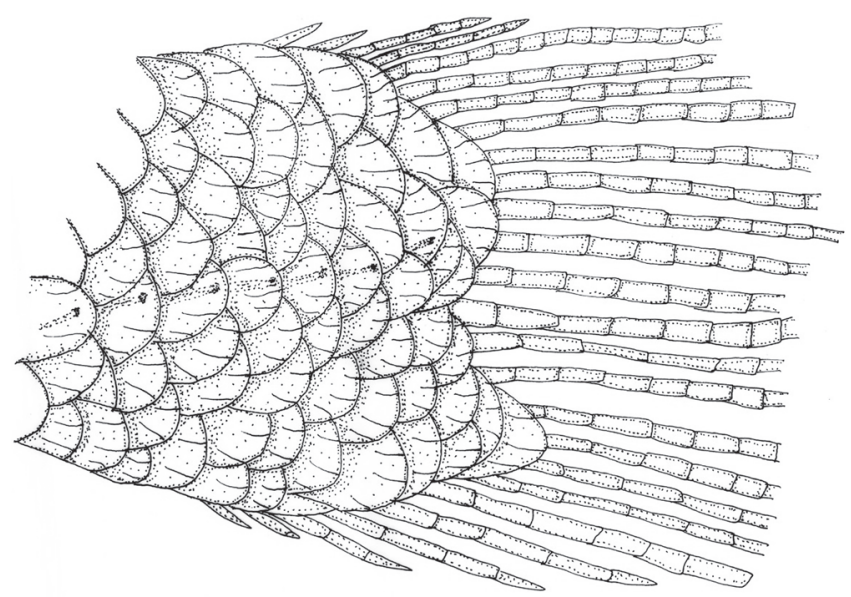

Fig. 10. Lepidocharax burnsi, MCP 27915, paratype, male, $32.7 \mathrm{~mm}$ SL. Caudal-fin squamation, lateral view, left side. 
Distribution. This species was collected from tributaries of the upper rio São Francisco and rio Doce basins (Fig. 6).

Etymology. Lepidocharax burnsi is named in honor of John $\mathrm{R}$. Burns for his outstanding contribution to the knowledge of histology of small inseminating characids.

Sexual dimorphism. Sexually mature males of the two new species have hooks on anal-and pelvic-fin rays, and proportionally longer pectoral and pelvic-fins, the tip of the former reaching pelvic-fin origin, and the tip of the latter reaching anal-fin origin.

Histological analysis. The two new species have spermatozoa with ovoid nuclei, and packs of spermatozoa were observed within the ovaries of females (Fig. 11). Sexually mature males of both new species also have gill glands, consisting of modifications the first gill arches and the development of five gill filaments and four chambers.

\section{Discussion}

In Mirande's (2010) hypothesis, the basal lineages of the expanded Stevardiinae form a large polytomy. In the present paper a resolved phylogenetic hypothesis of relationships for the Stevardiinae was obtained with the introduction of secondary sexual characters. From a total of 141 synapomorphies for the 16 nodes of the tree, 31 are based on sexually dimorphic characters (Table 3 ). This represents $22 \%$ of the total synapomorphies found, showing that phylogenetic relationships among small characids, should be based on as many characters as possible, including behavioral, reproductive, life colors, myological, and molecular.

According to our results, Lepidocharax is the sister group of all the remaining genera of the former Stevardiinae (Clade 3) sensu Weitzman et al. (2005), except Landonia, which is, in the present analysis, the sister group to Glandulocauda (Clade 18). Lepidocharax is morphologically very similar to Planaltina Böhlke (1954). Both have an elongated body, the dorsal-fin origin at a point vertically above the anal-fin base, and a dorsal groove on the anterior portion of frontals, immediately above eyes with a high concentration of neuromasts. Both genera can be distinguished from each other by the absence of modified scales forming a caudal gland on the caudal fin in Lepidocharax. Lepidocharax burnsi is also similar to Planaltina concerning sperm ultrastructure. The sperm nuclei of Planaltina (Fig. 12) species and L. burnsi (Fig. 13) are drop shaped and about $1.0 \mu \mathrm{m}$ in length, and contains highly condensed granular chromatin (Fig. 12). The centrioles have the same position in relation to one another and are located at the tip of the nucleus. Considering that their original position in the early spermatids was medial to the base of the nucleus, the nuclear rotation toward the flagellar axis can be calculated at about 125 degrees. Consequently the flagellum is lateral to the nucleus. In both species, the strongly asymmetric midpiece has a conical trunk shape and is located at the base of the nucleus. In the midpice, there are several spherical mitochondria and no vesicles. In contrast the sperm of $L$. diamantina (Fig. 14 ) is distinct from those of $L$. burnsi, and Planaltina. Its nucleus is ovoid ( $0.66 \mu \mathrm{m}$ in length) and also contains highly condensed granular chromatin in which the centrioles are lateral and located almost at the tip of the nucleus. Taking into account the centriole original position in the early spermatids (medial to the base of the nucleus) and their final position in the sperm, the nuclear rotation toward the flagellar axis was about 95 degrees. As the result of this rotation the flagellum is lateral to the nucleus. The strongly asymmetric midpiece has a semispherical shape and it is located at the base of the nucleus. In the midpiece, the mitochondria are elongate and there are a few large vesicles.

The discovery that the secretory cells of the caudal organ of the Glandulocaudinae (sensu Menezes \&Weitzman, 2009)

Table 3. Possible characters-state transformation for clades identified in Fig. 1. Characters (preceding colon) and characterstate (following colon) number correspond to those give in the text. In bold are the sexual characters.

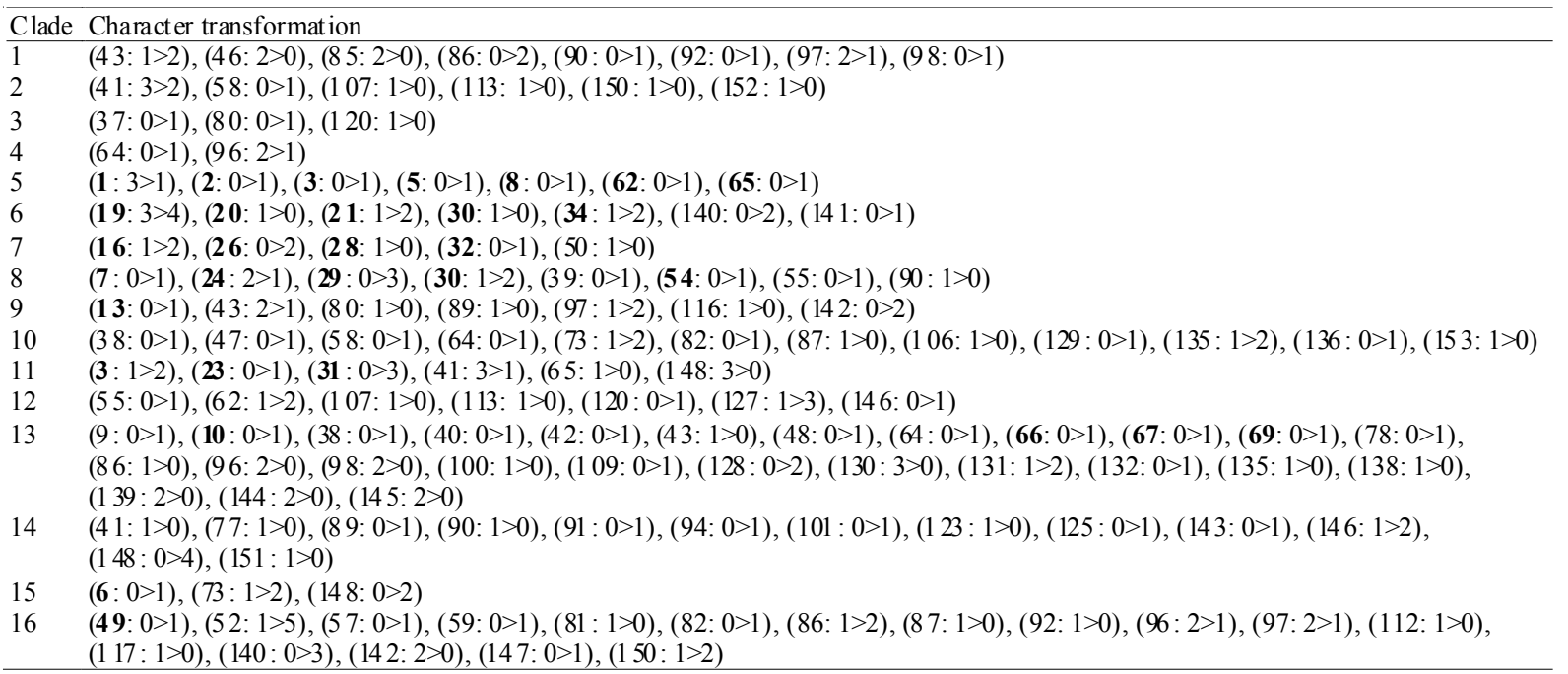



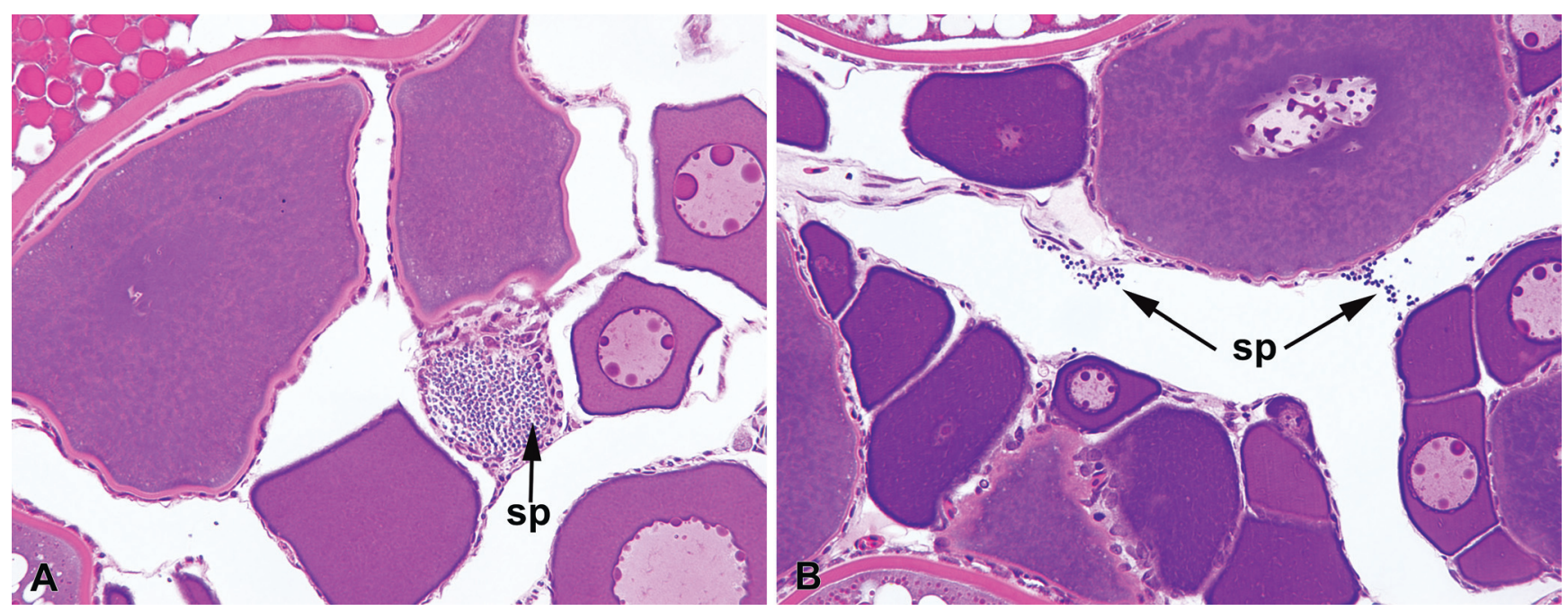

Fig. 11. Light micrographs through mature ovaries of Lepidocharax. Arrows show spermatozoa (sp). A: Lepidocharax diamantina (MNRJ 21997, 40.4 mm SL). B: Lepidocharax burnsi (MCP 34828, 29.9 mm SL).
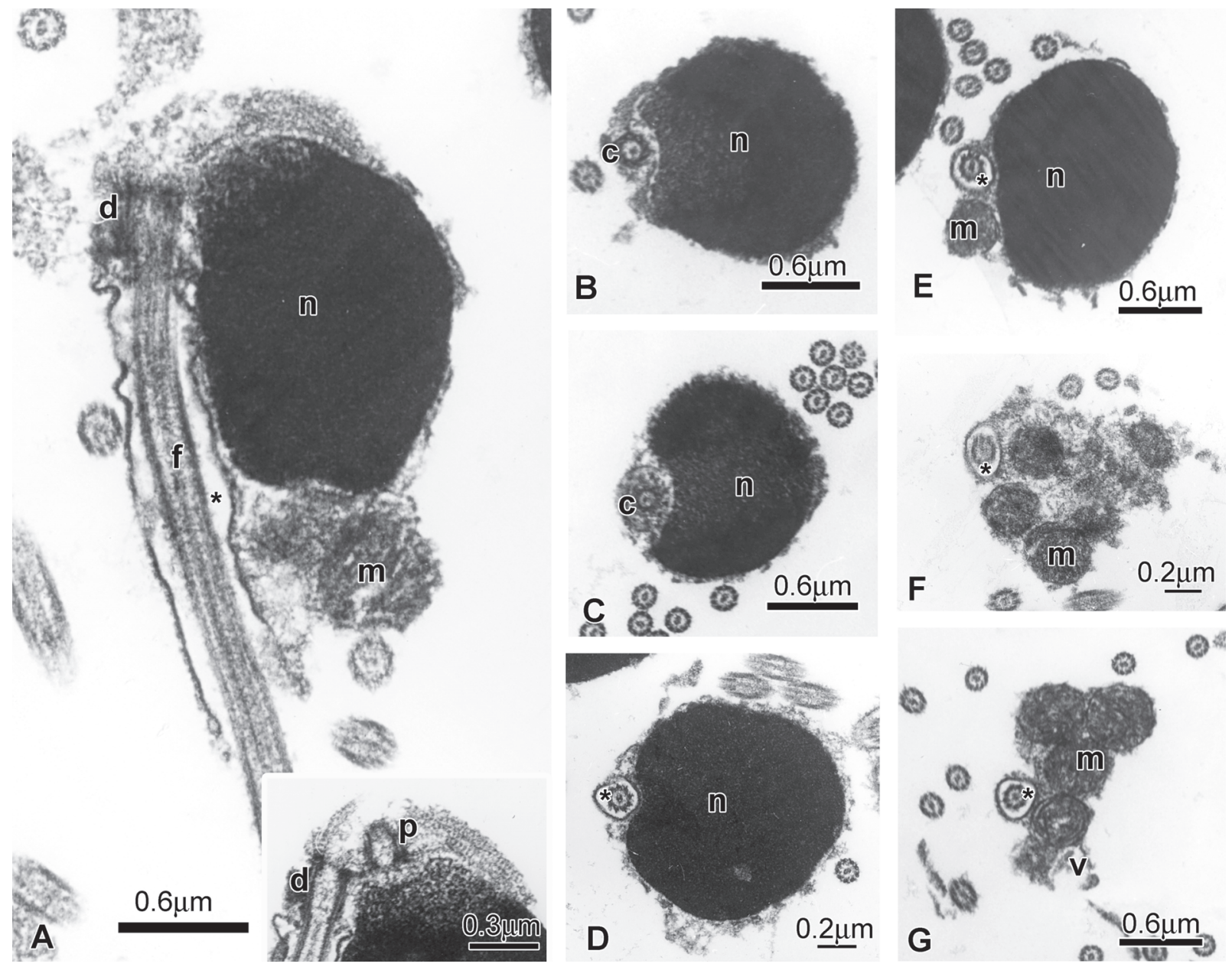

Fig. 12. Spermatozoa of Planaltina myersi (MZUSP 100642, $32.1 \mathrm{~mm} \mathrm{SL).} \mathrm{A:} \mathrm{Longitudinal} \mathrm{section} \mathrm{of} \mathrm{spermatozoa.} \mathrm{Note} \mathrm{the} \mathrm{lateral}$ position of the nucleus (n) in relation to the flagellar axis, the midpiece and the cytoplasmic canal $(*)$ into which is the initial segment of the flagellum (f). Inset: The proximal centriole is anterior and in an obtuse angle in relation to the distal centriole. Innumerable fibrils or striated centriolar rootlets radiate from the distal centriole (p), surround the tip of the nucleus forming a thick cap. B-E: Cross sections at different levels of the nucleus showing the lateral position of the distal centriole (c). F-G: Cross sections at different levels of the strongly asymmetric midpiece with some spherical mitochondria $(\mathrm{m})$ accumulated in major portion. 


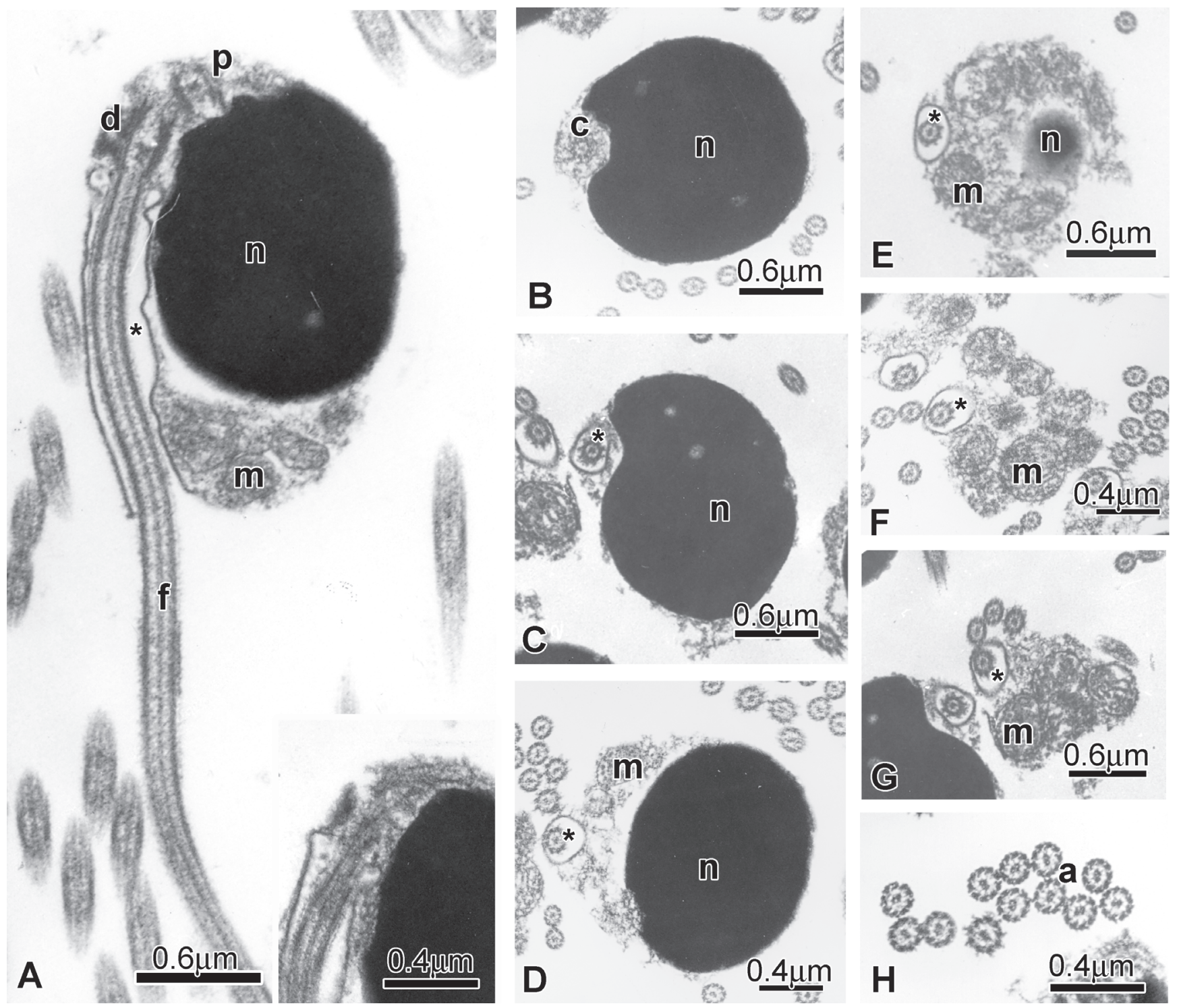

Fig. 13. Spermatozoa of Lepidocharax burnsi (MCP 34828, paratype, $31.9 \mathrm{~mm} \mathrm{SL}$ ) A: Longitudinal section of spermatozoa. Note the lateral position of the nucleus (n) in relation to the flagellar axis, the midpiece and the cytoplasmic canal $(*)$ into which is the initial segment of the flagellum (f). The distal and proximal centrioles are outside the single and shadow nuclear fossa. Inset: The centriolar complex is associated at the tip of the nucleus. B-D: Cross sections at different levels of the nucleus showing the lateral position of the distal centriole (c) and the flagellum (f). E-G: Cross sections at different levels of the strongly asymmetric midpiece with some spherical mitochondria $(\mathrm{m})$ accumulated in the major portion. $\mathbf{H}$ : Cross section of the flagella with the classic axoneme (a).

are histologically indistinguishable from secreting club cells rather than the derived mucous cells present in many groups of the Stevardiinae (sensu Menezes \& Weitzman, 2009), added support to the hypothesis that these subfamilies evolved independently from a Knodus-like ancestor (Weitzman et al., 2005; Menezes \& Weitzman, 2009). In view of the phylogenetic relationships described in the present paper, additional data resulting from histological sections carried out through all the fins of several characid groups herein studied deserve to be discussed. In such sections, both mucous and club cells are always present and this is not surprising because median fins are derived from the same fin fold extending from the dorsal median line around the tip of the tail to the ventral median line in the larvae that later in development differentiates into dorsal, caudal and anal fins (Takashima \& Aibiza, 1995). The epithelium is squamous due to the presence of external layers of calceiform (mucous) cells and also stratified because several layers of both calceiform cells and club cells are present. In the Stevardiinae species Corynopoma riisei Gill (Atkins \& Fink, 1979) and Hysteronotus megalostomus Eigenmann (Fig. 15), histological sections through the caudal gland region revealed the presence of hypertrophied mucous cells related to sexual pheromone production. John Burns (pers. commun.) observed the presence of hypertrophied 

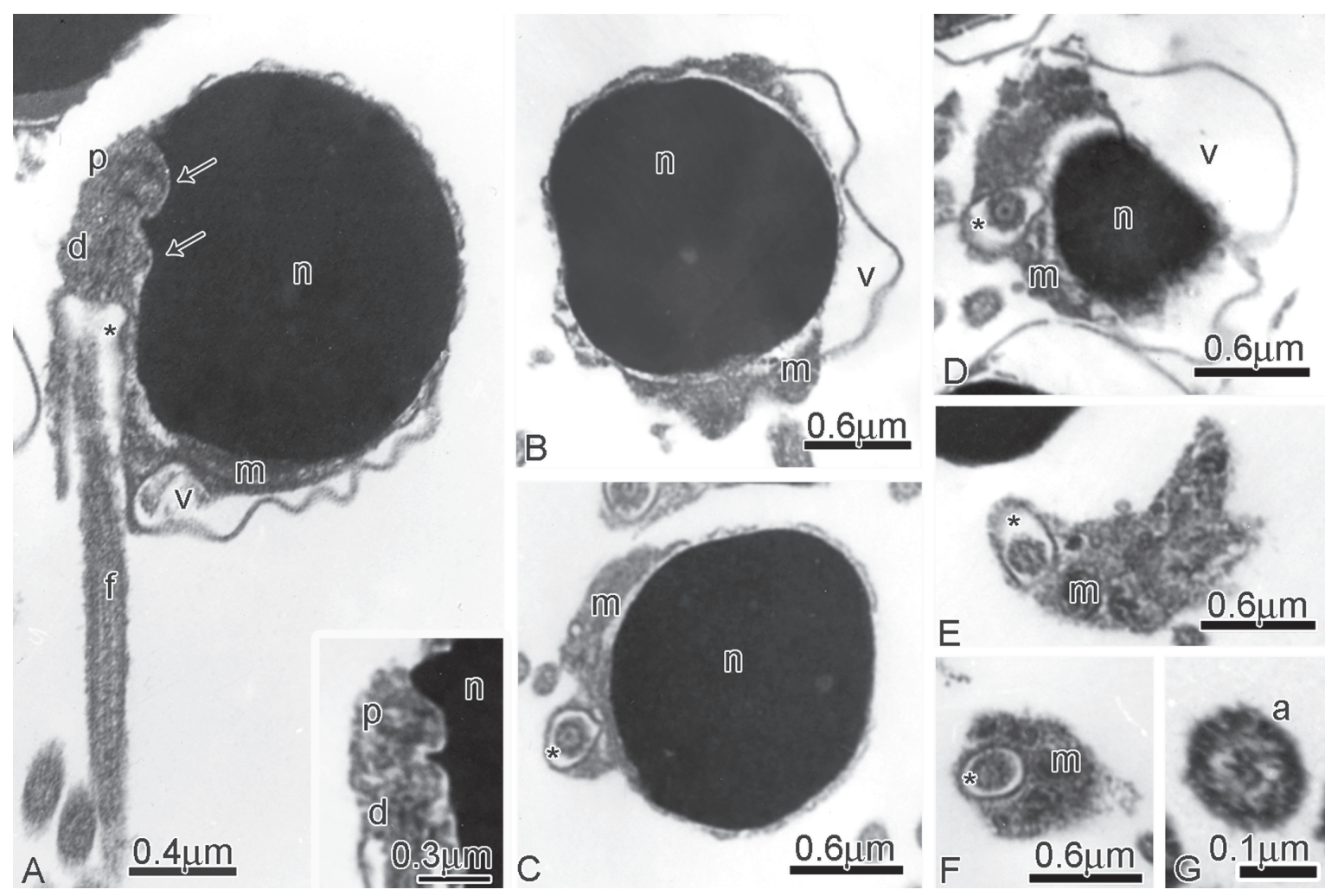

Fig. 14. Spermatozoa of Lepidocharax diamantina (MNRJ 21997, $34.7 \mathrm{~mm} \mathrm{SL}$ ) A: Longitudinal section of spermatozoa. Note the position of the nucleus (n) in relation to the flagellar axis, the position of the double nuclear fossa (double arrow), the midpiece and the cytoplasmic canal (*) into which is the initial segment of the flagellum (f). B-C: Cross sections at different levels of the nucleus showing large vesicles (v) in the surrounding cytoplasmic layer. D-F: Cross sections at different levels of the strongly asymmetric midpiece, from the base of the nucleus (n) to the midpiece end exposing the cytoplasmic canal $(*)$ and the distribution of the few elongate mitochondria $(\mathrm{m})$ accumulated in the major portion of the midpiece. G: Cross section of the flagella with the classic axoneme (a).
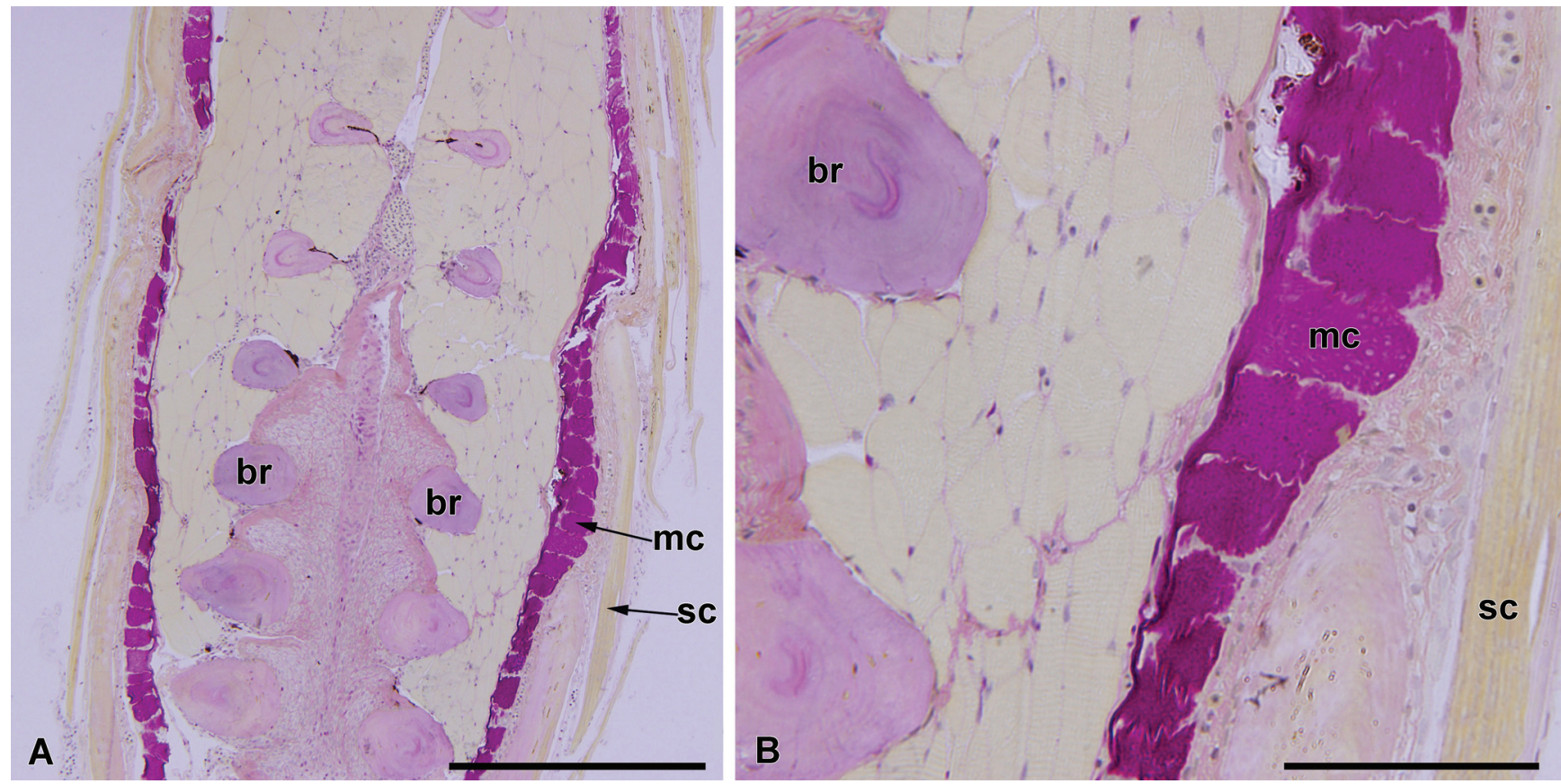

Fig. 15. Histological section carried out through caudal-fin of Hysteronotus megalostomus (MZUSP 85978, $34.9 \mathrm{~mm}$ SL); A: 10x magnification; B: 40x magnification; $\mathrm{sc}=$ scales; $\mathrm{mc}=$ mucous cells; $\mathrm{br}=$ branched ray. Scale $b a r=20 \mu \mathrm{m}$. 
mucous cells also in species of Acrobrycon, Pseudocorynopoma, and Corynopoma, but in our preparations none of the species either of Acrobrycon or Pseudocorynopoma examined presented those hypertrophied cells in the caudal-fin organ. In the species of Lophiobrycon, Glandulocauda, and Mimagoniates hypertrophied beaded tissue is present on median caudal-fin rays (Menezes \& Weitzman, 2009, figs. 5, 14, 23, 31, and 37) widespread over the caudal-fin rays in the basal genus Lophiobrycon or associated with structural modifications of principal caudalfin rays 11 and 12, simply curved in Glandulocauda and involved in the formation of a fin-ray pump in the more phylogenetically distal species of Mimagoniates (Menezes $\&$ Weitzman, 2009). So far as known, these modifications are not found in any other member of the Stevardiinae. In spite of the indication that in the above genera formerly included in the Glandulocaudinae of Weitzman \& Menezes, 2009, pheromone production is related to club cells (Weitzman et al., 2005; Menezes \& Weitzman, 2009), such cells

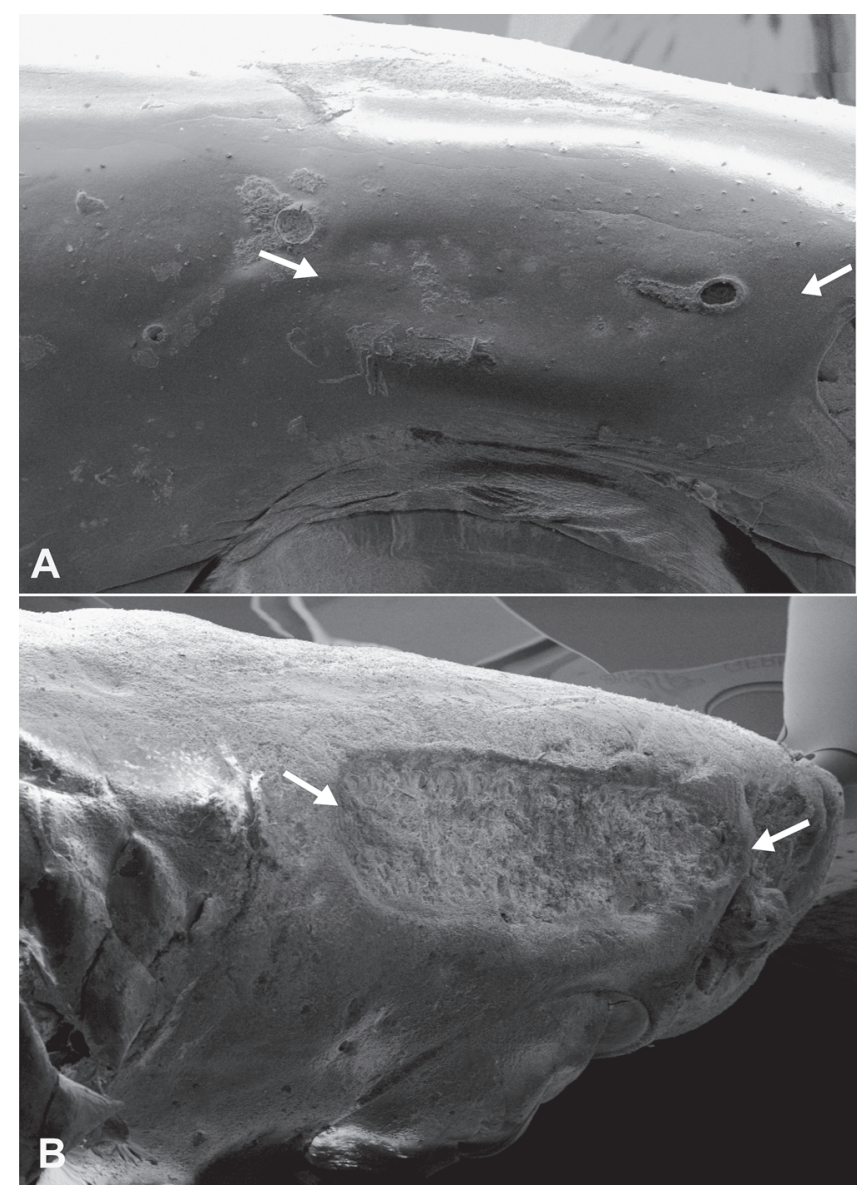

Fig. 16. Scanning electron micrograph of dorsal cranium region. Arrows evidencing the groove in the head above the eyes; A: Diapoma terofali (MCP 11491, 70x magnification) groove reduced, shallow, not well delineated and with only few neuromasts; B: Hysteronotus megalostomus (MZUSP 85978, 50x magnification) groove developed, depth, well delineated and with numerous neuromasts. Anterior to right. hypertrophied in the way the mucous cells are in Corynopoma and Hysteronotus have not been discovered in the glandular tissue on the caudal fin of any of these genera. However, since hypertrophied cells are only detected in sexually active "alpha males" examined during the process of courtship behavior (Atkins \& Fink, 1979), the origin of the pheromone in the members of Stevardiinae is still a question open to investigation. Association of behavioral, morphological, reproductive and molecular characters in the study of phylogenetic relationships is crucial for understanding the systematics and evolution of inseminating fishes.

Comparative material. Acrobrycon ipanquianus: MUSM 13232, 1 c\&s, 91.8 mm SL, Peru, Cuzco, La Convención, Quillabamba. Acrobrycon tarijae: CPUFMT 685, 1 c\&s, 78.1 $\mathrm{mm}$ SL, Argentina, Tucumán, Trancas, río Vipos, $5 \mathrm{~km}$ from ruta nacional 9. Attonitus irisae: MUSM 30270, 1 c\&s, 43.6 mm SL, Peru, Oxapampa, Palcazu, La Raya, R. Raya, Palcazu. Bryconacidnus ellisi: MUSM 11628, 1 c\&s, 25.5 mm SL, Peru, Sandia, Cuenca Ebehuabaeji. Bryconadenos tanaothoros: MZUSP 98979, 1 c\&s, 41.9 mm SL, Brazil, Mato Grosso, Nova Ubiratã, Xingu, rio Von den Steinen. Bryconadenos weitzmani: MZUSP 96559, 1 c\&s, 34 mm SL, Brazil, Pará, Altamira, Xingu, rio Curuá, rio Iriri basin, at Vila de Castelo dos Sonhos. Bryconamericus exodon: MZUSP 90715, 1 c\&s, $33.1 \mathrm{~mm} \mathrm{SL}$, Brazil, Mato Grosso, Barra do Bugres, Paraguai, Sepotuba. Ceratobranchia obtusirostris: MUSM 22306, 1 c\&s, $35.3 \mathrm{~mm}$ SL, Peru, La Convencion, Megantoni, Cuenca Bajo Urubamba, río Ticumpinía. Cyanocharax alburnus: MCP 19501, 1 c\&s, $49.7 \mathrm{~mm}$ SL, Brazil, Rio Grande do Sul, Jacuí, rio Taquari at Cruzeiro do Sul. Diapoma speculiferum: MCP 16617, 1 c\&s, 37.5 mm SL, Brazil, Rio Grande do Sul, Jacuí, arroio Santa Bárbara, $12 \mathrm{~km}$ West from Vila do Segredo. Diapoma terofali: MCP 11491, 1 c\&s, 50.1 mm SL, Brazil, Rio Grande do Sul, Uruguai, arroio Guarupá, boundary Quaraí/Alegrete. Gephyocharax atracaudata: MZUSP 19702, 1 c\&s, $41.9 \mathrm{~mm}$ SL, Panamá, tributary of Lake Miraflores. Glandulocauda melanopleura: CPUFMT 684, 1 c\&s, 38.8 mm SL, Brazil, São Paulo, Boracéia, tributary of rio Guaratuba. Hemibrycon surinamensis: MZUSP 30530, 1 c\&s, 46.1 mm SL, Brazil, Pará, Tocantins, rio Itacaiunas. Hysteronotus megalostomus: MZUSP 85978, 1 c\&s, 34.9 mm SL, Brazil, Minas Gerais, Montes Claros, São Francisco, rio Verde Grande. Landonia latidens: MZUSP 49195, 1 c\&s, 26.7 mm SL, Equador, Guayas, río Daule, $200 \mathrm{~m}$ above Coliares. Knodus meridae: MZUSP 99146, $1 \mathrm{c \& s}$, 39.2 mm SL, Venezuela, Mérida, río Chama, puente approx. 20 km NW of Mérida. Monotocheirodon personi: MUSM 11416, $1 \mathrm{c \& s}, 28.4 \mathrm{~mm}$ SL, Peru, Tambopata, río Malinowski, Quebrada Venado. Odontostoechus lethostigmus: MCP 13657, 1 c\&s, $37.7 \mathrm{~mm}$ SL, Brazil, Rio Grande do Sul, Tramandaí, arroio Água Parada, tributary of rio Maquiné at Maquiné. Phallobrycon adenacanthus: MZUSP 98902, 1 c\&s, 39.5 mm SL, paratype, Brazil, Mato Grosso, Paranatinga, Xingu, rio Culuene. Piabina argentea: MZUSP 88433, 1 c\&s, 40.2 mm SL, Brazil, Ipeúna, Ribeirão Passa Cinco, tributary of rio Corumbataí near SP310. Planaltina britskii: MZUSP 100643, 1 c\&s, 34.3 mm SL, 
Brazil, São Paulo, upper rio Paraná basin, rio Cubatão, bridge between Elisiário and Marapoama. Planaltina myersi: MZUSP 100642, 1 c\&s, 32.1 mm SL, Brazil, upper rio Paraná basin, Rio dos Patos. Pseudocorynopoma doriae: MZUSP 4479, 1 c\&s, $54.0 \mathrm{~mm}$ SL, Brazil, Rio Grande do Sul, São Leopoldo, rio dos Sinos, Porto do Vicente. Pseudocorynopoma heterandria: MZUSP 37273, 1 c\&s, 59.8 mm SL, Brazil, São Paulo, Ribeira, Arataca stream, tributary of rio Jacupiranga, road Pariqueraaçu-Iguape, $24^{\circ} 45^{\prime} \mathrm{S} 47^{\circ} 48^{\prime} \mathrm{W}$. Rhinobrycon negrensis: MUSM 4925, 1 c\&s, 27.9 mm SL, Peru, Manu, Quabrada Culli. Rhinopetitia myersi: DZSJRP 8499, 1 c\&s, 28.4 mm SL, Brazil, Mato Grosso, Ponte Branca, rio Araguaia, 16 $43^{\prime} 15^{\prime \prime S}$ 5245'59"W. Scopaeocharax rhinodus: MUSM 20370, 1 c\&s, $23.4 \mathrm{~mm}$ SL, Peru Tarapoto, Morales, San Antonio, río Cumbaza. Tetragonopterus argenteus: MZUSP 18798, 2 c\&s, 67.2-69.3 mm SL, Brazil, Mato Grosso, Barão de Melgaço, Boca do Croará, rio Cuiabá, $16^{\circ} 11^{\prime} \mathrm{S} 55^{\circ} 57^{\prime} \mathrm{W}$. Xenurobrycon macropus: MZUSP 96715, 1 c\&s, 13.7 mm SL, Brazil, Mato Grosso, Barão de Melgaço, Paraguai, rio Mutum, between vila de Mimoso and Joselândia.

\section{Acknowledgements}

We thank the editor and two anonymous reviewers for suggestion that improved the manuscript. We are very grateful to Stan Weitzman for English corrections and suggestions, Clarianna M. B. Silva for comments on the manuscript, Lara M. Guimarães for helping us with SEM preparations, Julio Santana (UNESP) for helping us with light microscopy preparation, Cláudio Oliveira (UNESP) for allowing us to use the microscope for slides photography. We are also very grateful to Flávio T. C. Lima (MZUSP) for collecting and making available to us all specimens of Lepidoracharax diamantina used in this work. We thank the following people for the loan of specimens: José Lima de Figueiredo, Mário C. C. de Pinna, and Oswaldo T. Oyakawa (MZUSP), Francisco Langeani (DZSJRP), Roberto E. Reis, and Zilda M. Lucena (MCP), Luiz R. Malabarba (UFRGS), Marcelo Britto (MNRJ), Francisco Provenzano (MBUCV), Hernán Ortega (MUSM), and Mark Sabaj and John Lundberg (ANSP). Authors receive financial support from the Fundação de Amparo a Pesquisa do Estado de São Paulo - FAPESP: KMF (fellowship 07/527560), NAM (fellowship 07/52755-4).

\section{Literature Cited}

Atkins, D. L. \& W. L. Fink. 1979. Morphology and histochemistry of the caudal gland of Corynopoma riisei Gill. Journal of Fish Biology, 14: 465-469.

Fink, W. L. \& S. H. Weitzman. 1974. The so-called cheirodontin fishes of Central America with descriptions of two new species (Pisces: Characidae). Smithsonian Contributions to Zoology, 172: 1-46.

Goloboff, P. A., J. S. Farris \& K. Nixon. 2003. TNT: Tree Analysis Using New Tecnology. Version 1.1, Software and documentation available from the authors and at http://zmuc.dk/public/ phylogeny.
Malabarba, L. R. \& S. H. Weitzman. 2003. Description of a new genus and six new species from Southern Brazil, Uruguay and Argentina with a discussion of a putative characid clade (Teleostei: Characiformes: Characidae). Comunicações do Museu de Ciências e Tecnologia, PUCRS. Série Zoologia, 16: 67151.

Menezes, N. A. \& S. H. Weitzman. 2009. Systematics of the neotropical fish subfamily Glandulocaudinae (Teleostei: Characiformes: Characidae). Neotropical Ichthyology, 7: 295370.

Mirande, J. M. 2010. Phylogeny of the family Characidae (Teleostei: Characiformes): from characters to taxonomy. Neotropical Ichthyology, 8(3): 385-568.

Page, R. D. M. 2001. NDE. Nexus Data Editor for Windows. v.0.5.0. http://taxonomy.zoology.gla.ac.uk/rod/rod.html

Reynolds, E. S. 1963. The use of lead citrate at high $\mathrm{pH}$ as an electron opaque stain in electron microscopy. Journal of Cell Biology, 17: 208-212.

Takashima, F. \& T. Hibiya. 1995. An atlas of fish histology: normal and pathological features. Second edition. Tokyo, Kodansha, $195 \mathrm{p}$.

Taylor, W. R. \& G. C. van Dyke. 1985. Revised procedures for staining and clearing small fishes and other vertebrates for bone and cartilage study. Cybium, 9: 107-119.

Vari, R. P. \& A. S. Harold. 2001. Neotropical fishes of the genus Creagrutus (Teleostei: Ostariophysi: Characiformes): A phylogenetic study and a revision of the species east of the Andes. Smithsonian Contributions to Zoology, 612: 1-239.

Weitzman, S. H. 1962. The osteology of Brycon meeki, a generalized characid fish, with an osteological definition of the family. Stanford Ichtyological Bulletin, 8: 1-77.

Weitzman, S. H. \& N. A. Menezes. 1998. Relationships of the tribes and genera of the Glandulocaudinae (Ostariophysi: Characiformes: Characidae) with a description of a new genus, Chrysobrycon). Pp. 171-192. In: Malabarba, L. R., R. E. Reis, R. P. Vari, Z. M. Lucena \& C. A. Lucena (Eds.). Phylogeny and classification neotropical freshwater fishes. Porto Alegre, Edipucrs.

Weitzman, S. H., N. A. Menezes, H. G. Evers \& J. R. Burns. 2005. Putative relationships among inseminating and externally fertilizing characids, with a description of a new genus and species of Brazilian inseminating fish bearing an anal-fin gland in males (Characiformes: Characidae). Neotropical Ichthyology, 3: 329-360.

Zanata, A. M. \& A. Akama. 2004. Myxiops aphos, new characid genus and species (Characiformes: Characidae) from the rio Lençois, Bahia, Brazil. Neotropical Ichthyology, 2: 45-54

Accepted April 26, 2011

Published June 30, 2011 


\section{Appendix 1. Characters used in the cladistic analysis of the genus Lepidocharax.}

1. Caudal-fin scales: (0) present only at base of the caudal fin; (1) more numerous on dorsal lobe; (2) covering equal portions of dorsal and ventral lobes.

2. Caudal pouch or sac on ventral caudal-fin lobe: (0) absent; (1) present.

3. Pouch scales (Weitzman \& Menezes, 1998, character 3): (0) no obvious pouch scale; (1) a large scale without hypertrophied radii forming part of posterior border of pouch (this pouch scale equals posterior terminal scale of first scale row ventral to lateral line row); (2) pouch scale with hypertrophied radii and extremely large, its greatest vertical dimension more than half of length between hypural fan and posterior tip of central caudal fin ray.

4. Scales of dorsal caudal-fin lobe: (0) not involved in caudalfin organ; (1) extend posteriorly to cover organized caudal glandular tissue.

5. Scales of ventral cauda-fin lobe: (0) not involved with a caudal sac or glandular organ; (1) extending posteriorly and involved with a caudal sac and glandular organ.

6 . Distinct lobes extending posteriorly from posterior border of pouch scale: (0) only a central lobe present, often poorly developed, weakly attached to fin rays by connective tissue; (1) two lobes present, a central and a ventral one.

7. Pouch scales of ventral caudal-fin lobe in females equivalent or nearly so in size and development with those in males: (0) absent; (1) present.

8. Scales of ventral caudal-fin lobe: (0) not hypertrophied; (1) hypertrophied.

9. Number of pouch scale radii: (0) fewer than 35 on posterior field of pouch scale; (1) 35 to 165 on posterior field of pouch scale.

10. Pouch scales: (0) without anteroventrally located process;

(1) with anteroventrally located process.

11. Distribution of pouch scale radii: (0) spread over entire posterior border of pouch scale; (1) confined to posterior ventral border.

12. Gill gland: (0) present; (1) absent.

13. Gland position on first gill arch: (0) restricted to hypobranchial and ceratobranchial anterior portion; (1) covering almost entirely the ceratobranchial.

14. Insemination: (0) absent; (1) present.

15. Nuclear rotation in type I spermiogenesis: (0) partial/ superior to $10^{\circ}$; (1) partial/inferior to $10^{\circ}$.

16. Nucleus format: (0) spherical (diameter $=1.0-2.0 \mu \mathrm{m})$; (1) slightly elongated toward the flagellum (longitudinal axis $>$ 2.0 and $<5.0 \mu \mathrm{m}$ ); (2) elongated toward the flagellum (longitudinal axis $>5.0$ and $<10 \mu \mathrm{m}$ ); (3) strongly elongated toward the flagellum (longitudinal axis $>10.0$ and $<20.0 \mu \mathrm{m}$ ); (4) strongly elongated toward the flagellum (longitudinal axis $>20.0 \mu \mathrm{m}$ ), with compressed outline; (5) strongly elongated toward the flagellum (longitudinal axis $>20.0 \mu \mathrm{m}$ ), with irregular outline; (6) strongly elongated toward the flagellum (longitudinal axis $>20.0 \mu \mathrm{m}$ ), with helical format.
17. Chromatin final aspects: (0) compact granular material (1) not compact aggregates with a flocculent appearance.

18. Nuclear fossa: (0) present; (1) absent.

19. Position of nuclear fossa: (0) eccentric; (1) basal and strongly eccentric;

(2) lateral and basally located; (3) lateral and located almost at tip of nucleus; (4) anterior or located at the tip of nucleus.

20. Depth of nuclear fossa: (0) shallow (housing part of centrioles); (1) very shallow (centrioles located outside fossa). 21. Position of nuclear fossa in relation with nucleus: (0) posterior; (1) lateral; (2) anterior.

22. Position of centriole relative to nuclear fossa: (0) Proximal centriole inserted and distal, partially inserted into nuclear fossa; (1) only the proximal centriole partially inserted in the nuclear fossa; (2) centriole not inserted into nuclear fossa. 23. Relative position of centriole: (0) proximal centriole perpendicular to the distal centriole; (1) proximal centriole oblique acute angle in relation to the distal centriole; (2) proximal centriole oblique obtuse angle in relation to the distal centriole.

24. Anchoring fibrils: (0) few, not forming bundles; (1) numerous, forming bundles; (2) forming developed bundles with striated aspect.

25. Midpiece shape: (0) narrowing in flagellum direction; (1) width not varying across length.

26. Length of midpiece: $(0)$ short (longitudinal axis $=0.0-2.0$ $\mu \mathrm{m})$; (1) intermediate (longitudinal $=2.1-3.0 \mu \mathrm{m}$ ); (2) long (longitudinal axis more than $3.0 \mu \mathrm{m}$ ).

27. Position of midpiece in relation to flagellum: (0) asymmetric; (1) strongly asymmetric.

28. Cytoplasmic sleeve: (0) present; (1) absent.

29. Position of mitochondria in relation to nucleus: (0) basal; (1) lateral; (2) basal and lateral; (3) basolateral; (4) brought.

30. Number of mitochondria: (0) few (1-5); (1) moderate (5-10); (2) many (more than 10).

31. Shape of mitochondria: (0) oblong (major axis more than 1 and less than 1.5 times in length of minor axis); (1) elongated (major axis more than 1.5 and less than 5 times in length of minor axis); (2) very long (major axis more than 5 times in length of minor axis); (3) very long (major axis more than 5 times in length of minor axis) and spiraled; (4) very long (major axis more than 5 times in length of minor axis) with irregular outline.

32. Position of mitochondria in relation to nucleus: (0) posterior; (1) lateral.

33. Position of posterior flagellum in relation to nucleus: (0) eccentric; (1) strongly eccentric and located almost in lateral position in relation to base of nucleus.

34. Position of lateral flagellum in relation to nucleus: (0) associated just in apical region; (1) associated over entire length; (2) partly associated along length.

35. Spermatozeugmata: (0) absent; (1) present.

36. Groove in head above the eyes: (0) absent; (1) reduced, shallow, not well delineated and containing only few neuromasts; (2) developed, deep, well delineated and containing numerous neuromasts (Fig. 16). 
37. Total number of pelvic fin rays: (0) eight; (1) seven.

38. Last pelvic-fin ray: (0) branched; (1) unbranched

39. Position of dorsal longitudinal ridge of pelvic bone: (0) located along lateral margin; (1) located more internally in relation to the outer margin.

40. Ossified posterior portion of ossified posterior pelvic process (Weitzman \& Menezes, 1998, character 19): (0) elongate; (1) reduced relative to its shape in outgroup stevardiines and other characiforms.

41. Anterior tip of pelvic bone (Weitzman \& Menezes, 1998, modified from character 20): (0) anterior to first rib; (1) between first and second pleural ribs; (2) between second and third pleural ribs; (3) between third and fourth pleural ribs; (4) between fourth and fifth pleural ribs; (5) between fifth and sixth pleural ribs.

42. Cartilaginous portion of pelvic-fin posterior process (Weitzman \& Menezes, 1998, character 36): (0) present; (1) absent.

43. Number of branched dorsal-fin rays: (0) 7 ; (1) 8 ; (2) 9 ; (3) 10.

44. Relative position of dorsal fin: (0) dorsal fin-origin anterior to vertical line through anal-fin origin (1) dorsal-fin origin vertically below or posterior to the vertical line through anal fin-origin.

45. Posterior margin of base of last dorsal-fin ray: (0) anterior to or at same vertical line through anal-fin origin; (1) posterior to vertical line through anal-fin origin.

46. Number of supraneurals: (0) eight; (1) seven; (2) six; (3) five; (4) four.

47. Shape of supraneurals: (0) tubular, width not varying across length; (1) bone flaps present, expanding bone dorsally.

48. Number of anal-fin rays: (0) more than eighteen; (1) eighteen or fewer branched anal-fin rays in both sexes.

49. Anterior anal-fin lobe: (0) anal fin without anterior lobe, straight along its ventral margin through whole fin extension; (1) anterior portion of anal fin expanded in a well- developed anterior lobe, followed by a posterior portion with a straight margin.

50. Number of proximal radials anterior to first haemal spines: (0) none; (1) up to two; (2) three or four.

51. Large median keel on anal-fin proximal radial: (0) large medial keel present, projected forward from main axis present only on first proximal radial; (1) present on first proximal radial and also on last sixth to seventh proximal radials.

52. Position of anterior margin of first anal-fin median radial: (0) on third pterygiophore; (1) on fourth pterygiophore; (2) on fifth pterygiophore; (3) on sixth pterygiophore; (4) on seventh pterygiophore; (5) on eleventh pterygiophore.

53. Glandular tissue on anal fin: (0) absent; (1) present.

54. Position of anal-fin rays hooks on mature males: (0) hooks inserted along posterior margin of anal-fin rays; (1) hooks distributed laterally over anal-fin rays; (2) hooks distributed both laterally and along the posterior margin of anal-fin rays. 55. Postcleithrum 1: (0) present; (1) absent.
56. Size of postcleithrum 1: (0) equal to or larger than size of scale located near operculum; (1) smaller than size of scale located near the operculum.

57. Postcleithrum 2: (0) present; (1) absent.

58. Structure of postcleithrum 3: (0) postcleithrum 3 without laminar expansions of bone along its entire length; (1) laminar expansion of bone anterior and posterior to main axis of postcleithrum 3 .

59. Shape of coracoid: (0) not expanded; (1) expanded ventrally forming a keel.

60. Number of epurals: (0) one; (1) two; (2) three.

61. Number of uroneurals: (0) two pairs; (1) one pair.

62. Scales bordering main portion of posterolateral border of caudal pouch opening (Weitzman \& Menezes, 1998, character 8): (0) none; (1) several scales of about equal size with no hypertrophied radii either in size or number; (2) one obviously large pouch scale with or without hypertrophied radii.

63. Median principal caudal-fin rays (Weitzman \& Menezes, 1998, character 9): (0) rays 11 and 12 not involved in formation of caudal pump; (1) rays 11 and 12 only decurved; (2) rays 1113 and sometimes 14 modified to form a caudal pump.

64. Parhypural and hypural one (Weitzman \& Menezes, 1998, character 12): (0) separated; (1) either contacting each other and leaving a narrow joint line, or fused to each other.

65. Scales covering dorsal border or region of caudal-fin pouch (Weitzman \& Menezes, 1998, character 18): (0) scales not modified, pouch absent, or if pouch present modified scales few in number; (1) multiple series of scales just ventral to lateral-line series extending posteriorly to form dorsal border of pouch opening.

66. Principal caudal-fin rays 11 to about 14 (Weitzman \& Menezes, 1998, character 30): (0) not narrow distally and sometimes shortened; (1) narrow distally and sometimes shortened.

67. Principal caudal-fin rays 1-8 and 16-19 plus largest ventral procurrent ray (Weitzman \& Menezes, 1998, character 31): (0) never expanded in sagital plane; (1) expanded in sagital plane. 68. Distance between bases of caudal-fin rays 10 and 11 excluding unciform process (Weitzman \& Menezes, 1998, character 44): (0) greater than posterior vertical border of hypural 3 ; (1) approximately equal to or less than vertical length of posterior margin of hypural bone 3 .

69. Distal halves of principal caudal-fin rays 7-10 (Weitzman \& Menezes, 1998, character 29): (0) linear or modified, but not arched or curved ventrally; (1) strongly curved ventrally.

70. Caudal fin hooks: (0) absent; (1) present.

71. Lateral-line tube morphology: (0) lateral-line tube without laminar expansions of bone; (1) lateral-line tube with laminar expansions of bone located dorsally and ventrally its main axis.

72. Ventral procurrent rays: (0) not modified; (1) posteriormost procurrent rays expanded and flattened laterally.

73. Total numbers of vertebrae: (0) less than 34 ; (1) 34 to 38 ; (2) 39 or more.

74. Relative number of vertebrae: (0) number of pre-caudal 
vertebrae equal to or greater than number of caudal vertebrae; (1) number of pre-caudal vertebrae fewer than number of caudal vertebrae.

75. Number of vertebrae anterior to first dorsal fin pterygiophore: (0) 10 or less; (1) 11 to 13; (2) 14 to 17; (3) 18 or more.

76. Number of intermediate vertebra: $(0)$ intermediate vertebrae absent; (1) one; (2) two.

77. Prezygapophysis and postzygapophysis (Zanata \& Akama, 2004): (0) normal; (1) with elaborations.

78. Contact between neural zygapophysis: (0) postzygapophysis not articulated with prezygapophyses of posterior vertebrae; (1) postzygapophysis articulated with prezygapophysis of posterior vertebrae.

79. Size of last ribs: (0) reduced, half of size of remaining ribs; (1) same size of remaining ribs.

80. Haemal postzygapophysis: (0) appearing in penultimate or last precaudal vertebrae with pleural rib; (1) appearing in intermediate precaudal vertebrae.

81. Antorbital: (0) in contact with infraorbital 1; (1) not contacting infraorbital 1 .

82. Antorbital canal: (0) absent; (1) present.

83. Shape of antorbital bone: (0) elongated; (1) dorsal region slightly narrower, widening gradually in ventral region; (2) dorsal region slightly narrower, widening abruptly in the middle.

84. Shape of dorsal region of antorbital: (0) straight, without lateral projection; (1) with lateral projection.

85. Position of ventral region of lateral ethmoid wing relative to infraorbitals 1 and 2: (0) vertical through ventral region of lateral ethmoid wing anterior to first infraorbital posterior margin; (1) vertical through ventral region of lateral etmoid wing at junction between first and second infraorbital; (1) vertical through ventral region of lateral ethmoid wing posterior to second infraorbital anterior margin.

86. Length of the infraorbital 1: (0) smaller than infraorbital 2; (1) same size of infraorbital 2; (2) larger than infraorbital 2.

87. Laterosensory canal 1 of infraorbital 1: (0) totally lined up with bone flaps; (1) one of margins exposed as a result of reduction or absence of bone flaps.

88. Posterior margin of infraorbital 1: (0) same height as anterior margin of infraorbital 2; (1) shallower than anterior margin of infraorbital 2.

89. Infraorbital 4: (0) short, its width greater than its length; (1) as large as wide; (2) elongated, its length greater than its width; (3) triangular.

90. Length of posterior margin of infraorbital 4: (0) shallower than anterior margin; (1) as large as anterior margin or slightly larger.

91. Posterior branch of laterosensory canal of infraorbital 4 : (0) present; (1) absent.

92. Width of fifth infraorbital: (0) wide, length greater than height; (1) narrow, height greater than length.

93. Infraorbital 5: (0) sensory canal located near anterior margin of bone; (1) sensory canal located in middle of infraorbital 5 which is wider than deeper; (2) sensory canal located in middle of infraorbital 5 which is deeper than wide.

94. Length of infraorbital 6: (0) smaller than infraorbital 5; (1) as large as infraorbital 5.

95. Nasal: (0) tubular, with laminar bone expansion; (1) tubular, without bone expansion.

96. Anterior region of nasal bone: (0) not reaching lateral projection of mesethmoid; (1) reaching lateral projection of mesethmoid; (2) extending slightly beyond end of lateral projection of mesethmoid; (3) extending $1 / 4$ or more of its length end of lateral projection of mesethmoid.

97. Ascending premaxillary process: $(0)$ distant from nasal bone; (1) reaching $1 / 3$ or slightly less of nasal bone length; (2) reaching $1 / 2$ or more of nasal bone length.

98. Pore size of laterosensory canal of frontal bone: (0) small or medium, opening restricted to only one margin of sensory canal; (1) large, opening extending between two margins of sensory canal.

99. Cranial fontanel: (0) extending to mesethmoid; (1) not reaching mesethmoid.

100. Cranial fontanel extent: (0) cranial fontanel absent; (1) corresponds to about $1 / 3$ the distance between epiphyseal bar and mesethmoid; (2) corresponds to half or a little more of distance between epiphyseal bar and mesethmoid; (3) contacting mesethmoid.

101. Epioccipital bone process: (0) present; (1) absent.

102. Posttemporal fossa: (0) upper opening almost as large as lower opening and visible laterally; (1) upper opening larger than lower and side openings; (2) upper opening smaller than lower lateral opening scarcely visible laterally. 103. Tip of supraoccipital spine: (0) not extending beyond vertical line crossing posterior region of Weberian apparatus; (1) extending beyond vertical line crossing Weberian apparatus, reaching vertical line through first and third vertebrae.

104. Anterior portion of vomer: (0) almost twice as wider than posterior portion; (1) only slightly wider than posterior portion.

105. Rhinosphenoid dorsal extension: (0) absent; (1) present. 106. Posteroventral process of orbitosphenoid: (0) absent; (1) present.

107. Ectopterygoid-quadrate contact: (0) present; (1) absent. 108. Ectopterygoid X palatine size: (0) palatine bone twice or more as large as length of ectopterygoid; (1) palatine smaller than ectopterygoid; (2) palatine and ectopterygoid about same length.

109. Shape of ectopterygoid: (0) broad anteriorly, tapering abruptly posteriorly; (1) narrow anteriorly, tapering gradually posteriorly; (2) narrow, not tapering posteriorly.

110. Ectopterygoid concavity: (0) present along entire bone; (1) present on posterior portion only; (2) concavity absent (bone smooth).

111. Ectopterygoid-endopterygoid: (0) ectopterygoid anterior margin anterior to endopterygoid margin; (1) ectopterygoid and endopterygoid anterior margins extending anteriorly to 
about same level; (2) endopterygoid anterior margin extending beyond ectopterygoid margin.

112. Dorsal portion of metapterygoid: (0) without concavity; (1) with concavity.

113. Metapterygoid posterior margin: (0) concave; (1) with fenestra.

114. Position of fenestra or concavity of posterior region of metapterygoid: (0) on upper region; (1) on median region; (2) on inferior region.

115. Contact between posteroinferior region of metapterygoid and posterosuperior region of quadrate: (0) absent; (1) present.

116. Metapterygoid-quadrate fenestra: (0) round or vertically elongate; (1) horizontally elongate; (2) very elongate horizontally (width more than 3 times height).

117. Metapterygoid concavity: (0) absent; (1) restricted to median portion of metapterygoid; (3) along entire dorsal surface of metapterygoid.

118. Anteroventral region of metapterygoid and anterodorsal region of quadrate: $(0)$ in contact or just with small space between them; (1) with large space between them.

119. Shape of anterior upward arm of quadrate: (0) slim and long; (1) wide and short; (2) wide and long.

120. Palatine fenestra: (0) present; (1) absent.

121. Palatine position: (0) above mesopterygoid; (1) in contact with mesopterygoid, but not overlapping it dorsally; (2) separated from mesopterygoid by space.

122. Palatine shape: (0) middle portion narrow (forming a constriction in bone); (1) bone with square or rectangular form.

123. Hyomandibular dorsoposterior margin: (0) flat, without any process; (1) with very small lateral process; (2) with large process, but not extending beyond dorsal margin of bone.

124. Ascending process of premaxilla: (0) straight; (1) curved. 125. Position of ascending process of premaxilla: (0) adjacent to anterior margin of premaxilla or slightly curved posteriorly; (1) on median region of the premaxilla.

126. Number of premaxillary tooth row: (0) one; (1) two; (2) three.

127. Number of inner row premaxillary teeth: (0) three; (1) four; (2) five; (3) seven.

128. Size of outer row premaxillary teeth: (0) smaller than those of inner row; (1) larger than those of inner row.

129. Spaces between outer row premaxillary teeth: (0) present; (1) absent.

130. Inner row premaxillary with greater number of cusps: $(0)$

3 ; (1) 4 ; (2) 5 ; (3) 7.

131. Shape of inner row premaxillary teeth: $(0)$ tooth base smaller than crown; (1) base and crown about same size.

132. Inner row of premaxillary teeth: (0) wide; (1) narrow.

133. Position of maxillary posterior margin: (0) anterior to wing of lateral ethmoid; (1) Posterior to wing of lateral ethmoid.

134. Maxillary teeth: (0) absent; (1) present.

135. Length of anterior process in relation to posterior process of maxilla: (0) posterior process of same size or slightly larger than anterior process; (1) posterior process twice as large as anterior process; (2) posterior process smaller than anterior process.

136. Extension of maxillary toothed portion: (0) edentulous posterior process of maxillary about same size as toothed portion; (1) edentulous posterior process of maxillary smaller than toothed portion.

137. Number of maxillary teeth: ( 0 ) one to four; (1) five to 10 (2) more than 11.

138. Number of cusps of maxillary teeth: $(0)$ no cusps, teeth conical; (1) two; (2) three; (3) four; (4) five; (5) six; (6) seven. 139. Cusps size of maxillary teeth: (0) no lateral cusps, conical teeth; (1) all cusps of similar sizes; (2) median cusps larger than others.

140. Connection between two maxillary arms: $(0)$ formed by three interdigitations; (1) formed by four interdigitations; (2) formed by five interdigitations; (3) formed by six interdigitations; (4) formed by seven interdigitations.

141. Relative size of anterior toothed and posterior edentulous portions of dentary: (0) anterior portion longer than posterior; (1) anterior portion shorter than posterior.

142. First four anterior dentary teeth: (0) base and crown with same size; (1) base narrower than crown (2) base larger than crown.

143. Position of cusps of dentary teeth: (0) inclined posteriorly; (1) straight.

144. Size of cusps of four anterior dentary teeth: (0) teeth conical; (1) cusps with about same size; (2) median cusps larger than others.

145. Number of cusps of anteriormost four dentary teeth: (0) teeth conical; (1) three; (2) four; (3) five; (4) six; (5) seven. 146. Shape of implantation of four anterior dentary teeth in lateral view: (0) elliptic; (1) rounded; (2) horizontally straight. 147. Number of cusps of posterior dentary teeth: (0) teeth conical; (1) multicuspid.

148. Number of replacement fossae for dentary teeth: (0) first three teeth have each a fossa followed by a single cavity for posterior teeth; (1) a separate fosse for each of four anterior teeth, and none for posterior teeth; (2) a separate fossa for each of four anterior teeth, and a single fossa for posterior teeth; (3) a separate fossa for first two teeth followed by a single cavity for posterior teeth except for posteriormost, without cavities for replacemen teeth; (4) a single fossa for all teeth; (5) a fossa for each tooth. 149. Foramen in anterior ceratohyal anterior: (0) absent; (1) present.

150. Urohyal: $(0)$ with lateral wings extending to posterior portion of bone; (1) lateral wings extending to middle portion of bone; (2) lateral wings restricted to anterior portion of boneurohyal.

151. Basibranchial 4: (0) entirely cartilaginous; (1) in part ossified.

152. Pharyngeal 3: (0) with teeth; (1) without teeth.

153. Shape of basihyal: (0) anterior margin slightly wider than posterior margin; (1) basihyal anteriorly expanded. 


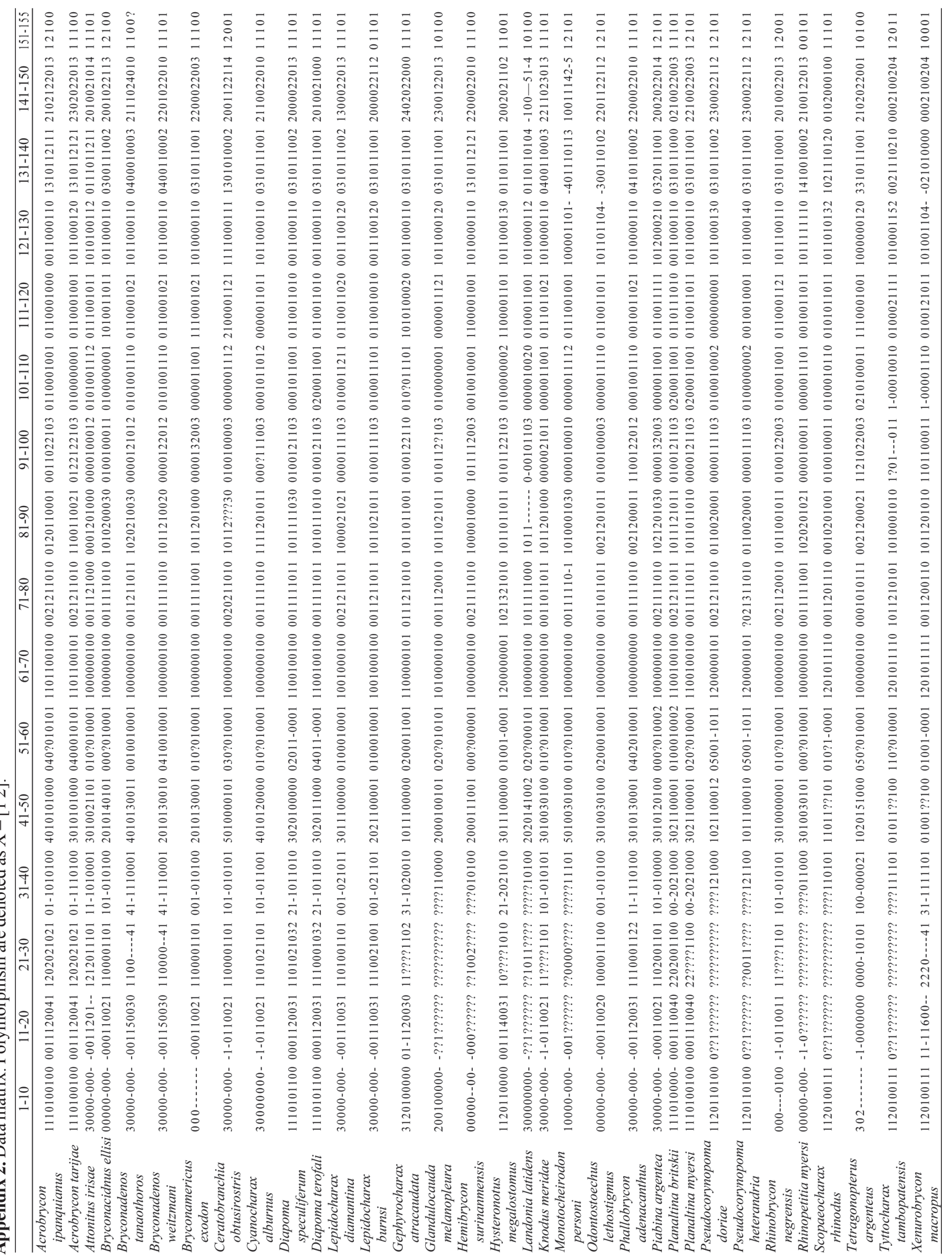

